Prepared in Cooperation with the Arizona Department of Water Resources

\title{
Hydrogeologic Framework of the Middle San Pedro Watershed, Southeastern Arizona
}

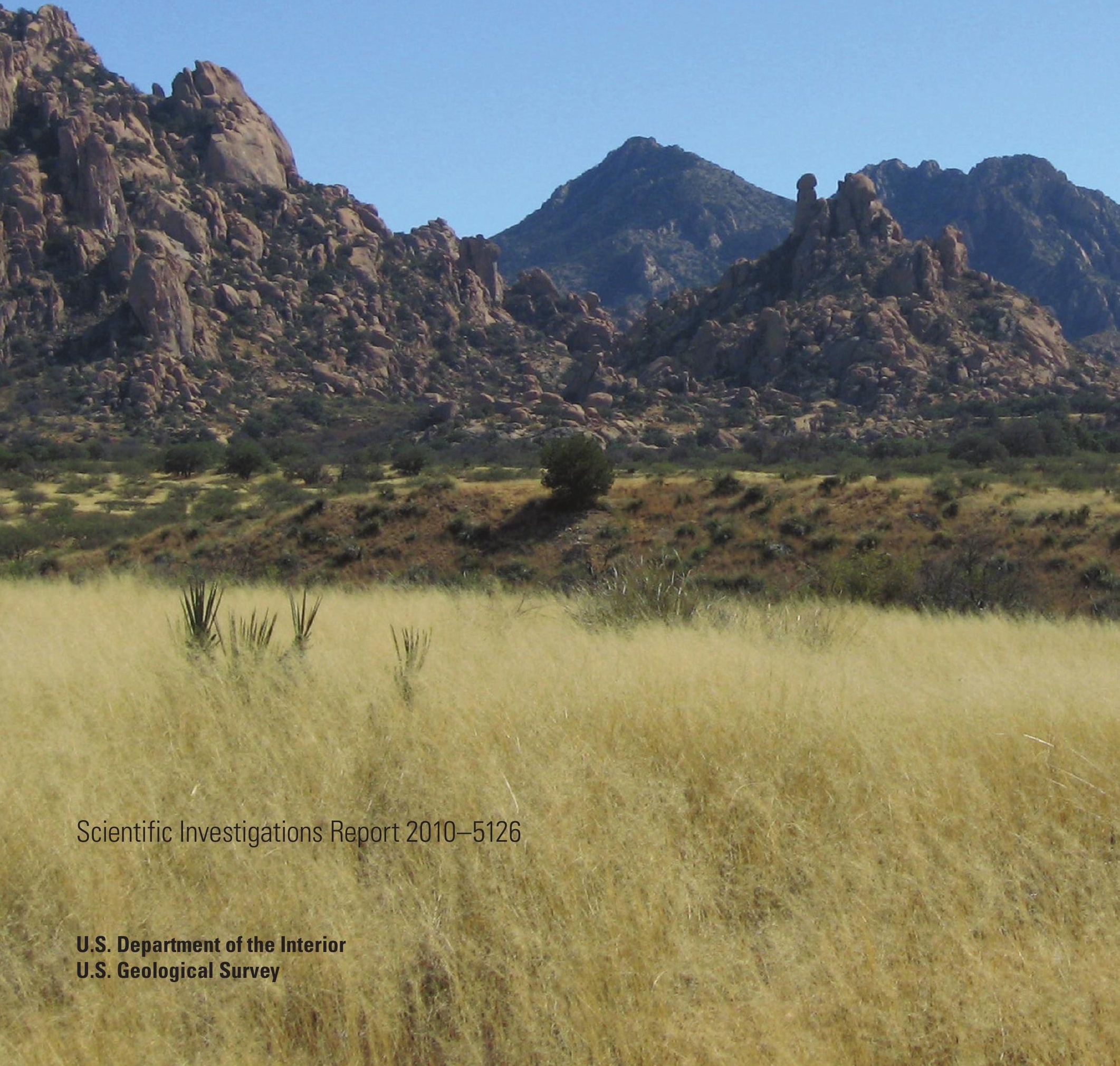


COVER:

View of the Dragoon Mountains looking eastward. Photo by Candice B. Adkins. 


\section{Hydrogeologic Framework of the Middle San Pedro Watershed, Southeastern Arizona}

By Jesse E. Dickinson, Jeffrey R. Kennedy, D.R. Pool, Jeffrey T. Cordova, John T. Parker, J.P. Macy, and Blakemore Thomas

Prepared in Cooperation with the Arizona Department of Water Resources

Scientific Investigations Report 2010-5126 


\section{U.S. Department of the Interior \\ KEN SALAZAR, Secretary}

\section{U.S. Geological Survey \\ Marcia K. McNutt, Director}

\section{U.S. Geological Survey, Reston, Virginia 2010}

For product and ordering information:

This report and any updates to it are available online at:

http://pubs.usgs.gov/sir/2010/5126/

World Wide Web: http://www.usgs.gov/pubprod

Telephone: 1-888-ASK-USGS (1-888-275-8747)

For more information on the USGS - the Federal source for science about the Earth, its natural and living resources, natural hazards, and the environment:

World Wide Web: http://www.usgs.gov/

Telephone: 1-888-ASK-USGS (1-888-275-8747)

Although this report is in the public domain, permission must be secured from the individual copyright owners to reproduce any copyrighted material contained within this report.

Any use of trade, product, or firm names is for descriptive purposes only and does not imply endorsement by the U.S. Government.

Suggested citation:

Dickinson, J.E., Kennedy, J.R., Pool, D.R., Cordova, J.T., Parker, J.T., Macy, J.P., and Thomas, B., 2010, Hydrogeologic framework of the middle San Pedro watershed, southeastern Arizona: U.S. Geological Survey Scientific Investigations Report 2010-5126, 36 p. 


\section{Contents}

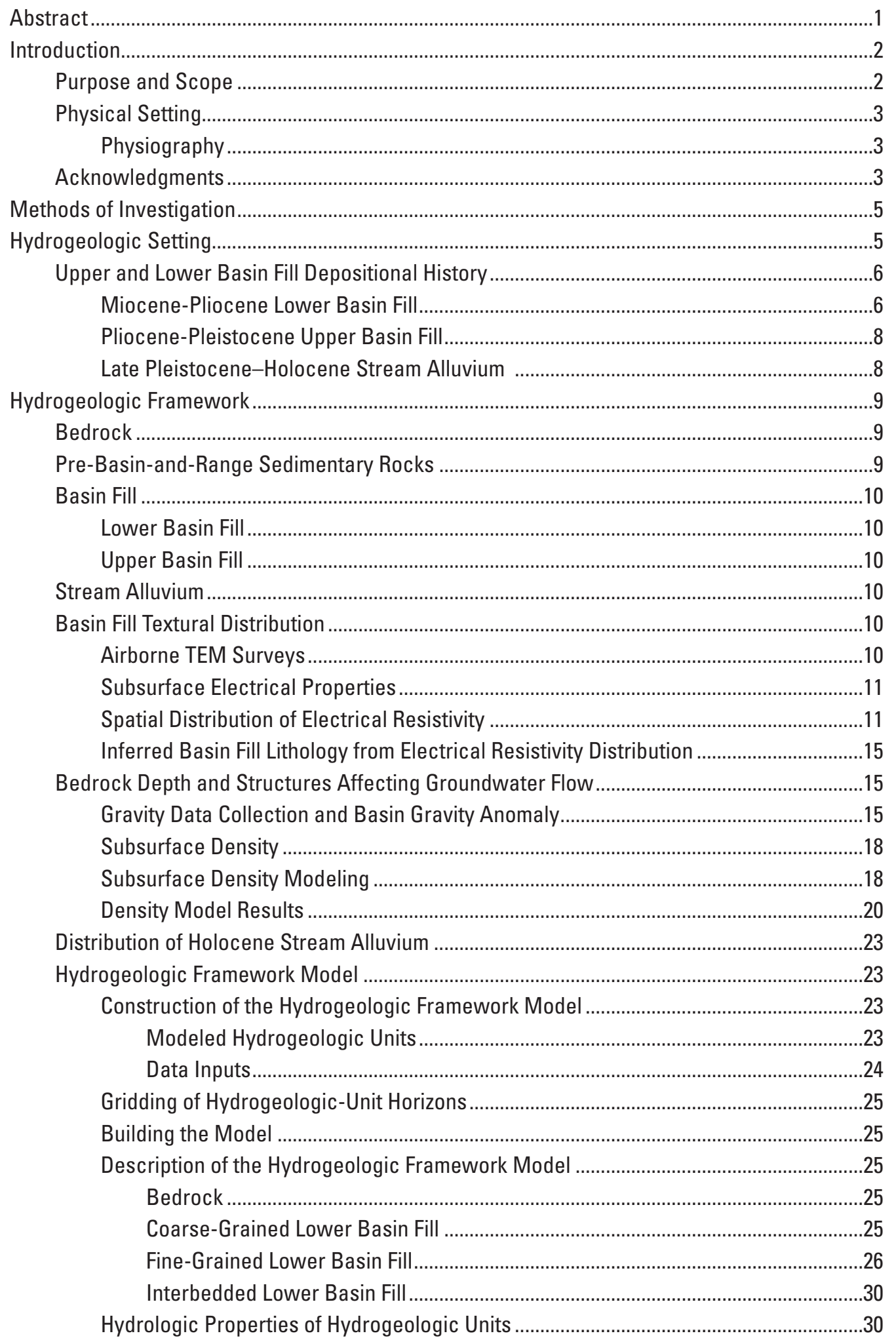




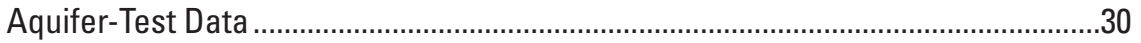

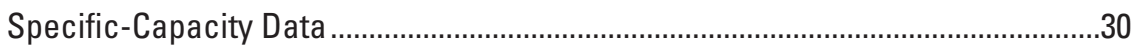

Saturated Thickness of Coarse-Grained Lower Basin Fill ........................................30

Incorporating the Hydrogeologic Framework Model into a Groundwater-Flow

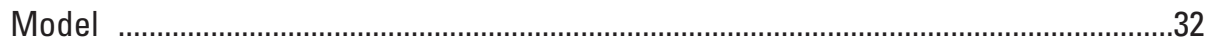

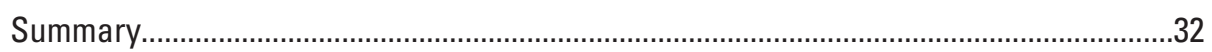

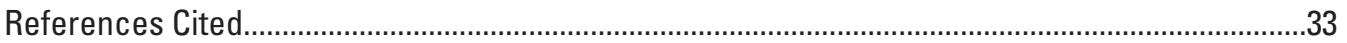

\section{Figures}

1. Map showing the middle San Pedro watershed, in southeastern Arizona. .................................4

2. Generalized geologic map of the middle San Pedro watershed, southeastern Arizona..............6

3. Generalized east-west section and stratigraphic units in the middle San Pedro watershed, southeastern Arizona.

4. Airborne transient electromagnetic (TEM) survey flight lines and interpolated resistivity values from one-dimensional resistivity models at a depth of $200 \mathrm{~m}$ in the middle San Pedro watershed, southeastern Arizona.

5. Locations of wells with geophysical logs and drill logs used in construction of the hydrogeologic framework model and the extent of the hydrogeologic framework model........13

6. Depths of the top of the lower basin fill and fine-grained and coarse-grained facies in the middle San Pedro watershed indicated by electrical resistivity and sonic velocity logs from four wells.

7. Section A-A' (fig.2) showing an stratigraphic interpretation on the basis of geophysical and lithologic data.

8. Section B-B' (fig. 2 ) showing an stratigraphic interpretation on the basis of geophysical and lithologic data.

9. Sites of gravity measurements in the middle San Pedro watershed and derived gravity anomaly used to estimate bedrock altitude.

10. Subsurface density profiles from wells and the gravity density function used to assign density of layers in the subsurface density model for the middle San Pedro watershed, southeast Arizona.

11. Section C-C' (fig. 9) showing the layers in the subsurface density model and gravity values.

12. Bedrock altitude determined from subsurface density model in the middle San Pedro watershed.

13. Oblique view of a 3D block diagram of the hydrogeologic framework model of the middle San Pedro watershed, southeastern Arizona.

14. Extent and saturated thickness of the coarse-grained lower basin fill hydrogeologic unit $(\mathrm{HGU})$ in the hydrogeologic framework model (HFM) of the middle San Pedro watershed, southeastern Arizona.

15. Extent and thickness of the fine-grained lower basin fill hydrogeologic unit (HGU) constructed by the hydrogeologic framework model (HFM) of the middle San Pedro watershed, southeastern Arizona.

16. Extent and thickness of the interbedded lower basin fill hydrogeologic unit (HGU) represented in the hydrogeologic framework model (HFM) of the middle San Pedro watershed, southeastern Arizona. 


\section{Tables}

1. Physical properties and ages of the stratigraphic units and hydrogeologic units in the middle San Pedro watershed, southeastern Arizona...........................................................................

2. Data sources for hydrogeologic units represented by the hydrogeologic framework model.

3. Available specific capacity data for wells in the middle San Pedro watershed, southeastern Arizona.. 


\section{Conversion Factors and Datum}

Inch/Pound to SI

\begin{tabular}{|c|c|c|}
\hline Multiply & By & To obtain \\
\hline \multicolumn{3}{|c|}{ Length } \\
\hline inch (in.) & 2.54 & centimeter $(\mathrm{cm})$ \\
\hline inch (in.) & 25.4 & millimeter (mm) \\
\hline foot $(\mathrm{ft})$ & 0.3048 & meter $(\mathrm{m})$ \\
\hline mile (mi) & 1.609 & kilometer $(\mathrm{km})$ \\
\hline \multicolumn{3}{|c|}{ Area } \\
\hline acre & 4,047 & square meter $\left(\mathrm{m}^{2}\right)$ \\
\hline acre & 0.004047 & square kilometer $\left(\mathrm{km}^{2}\right)$ \\
\hline \multicolumn{3}{|c|}{ Volume } \\
\hline acre-foot (acre-ft) & 1,233 & cubic meter $\left(\mathrm{m}^{3}\right)$ \\
\hline acre-foot (acre-ft) & 0.001233 & cubic hectometer $\left(\mathrm{hm}^{3}\right)$ \\
\hline \multicolumn{3}{|c|}{ Flow rate } \\
\hline acre-foot per year (acre-ft/yr) & 1,233 & cubic meter per year $\left(\mathrm{m}^{3} / \mathrm{yr}\right)$ \\
\hline acre-foot per year (acre-ft/yr) & 0.001233 & $\begin{array}{l}\text { cubic hectometer per year } \\
\left(\mathrm{hm}^{3} / \mathrm{yr}\right)\end{array}$ \\
\hline foot per year ( $\mathrm{ft} / \mathrm{yr}$ ) & 0.3048 & meter per year $(\mathrm{m} / \mathrm{yr})$ \\
\hline inch per year (in/yr) & 25.4 & millimeter per year $(\mathrm{mm} / \mathrm{yr})$ \\
\hline \multicolumn{3}{|c|}{ Specific capacity } \\
\hline $\begin{array}{l}\text { gallon per minute per foot } \\
[(\mathrm{gal} / \mathrm{min}) / \mathrm{ft})]\end{array}$ & 0.2070 & $\begin{array}{l}\text { liter per second per meter } \\
{[(\mathrm{L} / \mathrm{s}) / \mathrm{m}]}\end{array}$ \\
\hline \multicolumn{3}{|c|}{ Hydraulic conductivity } \\
\hline foot per day (ft/d) & 0.3048 & meter per day $(\mathrm{m} / \mathrm{d})$ \\
\hline \multicolumn{3}{|c|}{ Transmissivity* } \\
\hline foot squared per day $\left(\mathrm{ft}^{2} / \mathrm{d}\right)$ & 0.09290 & meter squared per day $\left(\mathrm{m}^{2} / \mathrm{d}\right)$ \\
\hline
\end{tabular}

Vertical coordinate information is referenced to the National Geodetic Vertical Datum of 1988 (NGVD 88).

Horizontal coordinate information is referenced to the North American Datum of 1983 (NAD 83).

Elevation, as used in this report, refers to distance above the vertical datum.

*Transmissivity: The standard unit for transmissivity is cubic foot per day per square foot times foot of aquifer thickness $\left[\left(\mathrm{ft}^{3} / \mathrm{d}\right) / \mathrm{ft}^{2}\right] \mathrm{ft}$. In this report, the mathematically reduced form, meter squared per day $\left(\mathrm{m}^{2} / \mathrm{d}\right)$, is used for convenience.

Specific conductance is given in microsiemens per centimeter at 25 degrees Celsius $\left(\mu \mathrm{S} / \mathrm{cm}\right.$ at $\left.25^{\circ} \mathrm{C}\right)$.

Concentrations of chemical constituents in water are given either in milligrams per liter (mg/L) or micrograms per liter $(\mu \mathrm{g} / \mathrm{L})$ 


\title{
Hydrogeologic Framework of the Middle San Pedro Watershed, Southeastern Arizona
}

\author{
By Jesse E. Dickinson, Jeffrey R. Kennedy, D.R. Pool, Jeffrey T. Cordova, John T. Parker, J.P. Macy, and \\ Blakemore Thomas
}

\section{Abstract}

Water managers in rural Arizona are under increasing pressure to provide sustainable supplies of water despite rapid population growth and demands for environmental protection. This report describes the results of a study of the hydrogeologic framework of the middle San Pedro watershed. The components of this report include: (1) a description of the geologic setting and depositional history of basin fill sediments that form the primary aquifer system, (2) updated bedrock altitudes underlying basin fill sediments calculated using a subsurface density model of gravity data, (3) delineation of hydrogeologic units in the basin fill using lithologic descriptions in driller's logs and models of airborne electrical resistivity data, (4) a digital three-dimensional (3D) hydrogeologic framework model (HFM) that represents spatial extents and thicknesses of the hydrogeologic units (HGUs), and (5) description of the hydrologic properties of the HGUs. The lithologic interpretations based on geophysical data and unit thickness and extent of the HGUs included in the HFM define potential configurations of hydraulic zones and parameters that can be incorporated in groundwater-flow models.

The hydrogeologic framework comprises permeable and impermeable stratigraphic units: (1) bedrock, (2) sedimentary rocks predating basin-and-range deformation, (3) lower basin fill, (4) upper basin fill, and (5) stream alluvium. The bedrock unit includes Proterozoic to Cretaceous crystalline rocks, sedimentary rocks, and limestone that are relatively impermeable and poor aquifers, except for saturated portions of limestone. The pre-basin-and-range sediments underlie the lower basin fill but are relatively impermeable owing to cementation. However, they may be an important water-bearing unit where fractured. Alluvium of the lower basin fill, the main waterbearing unit, was deposited in the structural trough between the uplifted ridges of bedrock and (or) pre-basin-and-range sediments. Alluvium of the upper basin fill may be more permeable than the lower basin fill, but it is generally unsaturated in the study area.

The lower basin fill stratigraphic unit was delineated into three HGUs on the basis of lithologic descriptions in driller's logs and one-dimensional (1D) electrical models of airborne transient electromagnetic (TEM) surveys. The interbedded lower basin fill (ILBF) HGU represents an upper sequence having resistivity values between 5 and $40 \mathrm{ohm}$-m identified as interbedded sand, gravel, and clay in driller's logs. Below this upper sequence, fine-grained lower basin fill (FLBF) HGU represents a thick silt and clay sequence having resistivity values between 5 and $20 \mathrm{ohm}-\mathrm{m}$. Within the coarse-grained lower basin fill (CLBF) HGU, which underlies the silt and clay of the FLBF, the resistivity values on logs and 1D models increase to several hundred ohm-m and are highly variable within sand and gravel layers. These sequences match distinct resistivity and lithologic layers identified by geophysical logs in the adjacent Sierra Vista subwatershed, suggesting that these sequences are laterally continuous within both the Benson and Sierra Vista subwatersheds in the Upper San Pedro Basin.

A subsurface density model based on gravity data was constructed to identify the top of bedrock and structures that may affect regional groundwater flow. The subsurface density model contains six layers having uniform density values, which are assigned on the basis of geophysical logs. The density values for the layers range between $1.65 \mathrm{~g} / \mathrm{cm}^{3}$ for unsaturated sediments near the land surface and $2.67 \mathrm{~g} / \mathrm{cm}^{3}$ for bedrock. Major features include three subbasins within the study area, the Huachuca City subbasin, the Tombstone subbasin, and the Benson subbasin, which have no expression in surface topography or lithology. Bedrock altitudes from the subsurface density model defined top altitudes of the bedrock HGU.

The HFM includes the following HGUs in ascending stratigraphic order: (1) bedrock and pre-basin-and-range sediments, (2) CLBF, (3), FLBF, and (4) ILBF. Data for the model includes digital elevation models, lithology from drill logs, geophysical borehole logs, one-dimensional layered profiles from electrical-resistivity models, and bedrock altitudes from subsurface density models. The saturated thickness of the CLBF varies in relation to the depth to underlying bedrock and to the presence of the overlying FLBF and IBLF that thicken in the basin center. Three areas where the saturated thickness of the CLBF is about $1,000 \mathrm{~m}$ are south of Redington, northwest of Benson, and southeast of St. David. The thickness is about $600 \mathrm{~m}$ in the southern portion of the study area near the 
Whetstone Mountains. Thin areas of the CLBF are largely the result of shallow bedrock that underlies much of the San Pedro River south of Benson and at The Narrows. The extent of the FLBF is limited to the central north-south-axis of the Benson subarea, and the thickness increases northward to about $300 \mathrm{~m}$ south of The Narrows. The ILBF is up to $100 \mathrm{~m}$ thick and is a transition between the CLBF and FLBF.

\section{Introduction}

Water managers in rural Arizona are under increasing pressure to provide sustainable supplies of water despite rapid population growth and demands for environmental protection. In the middle San Pedro watershed in southeastern Arizona (fig. 1), groundwater is the primary source of water for municipal, domestic, industrial, and agricultural use. Increased groundwater pumping could have several undesirable consequences, such as loss of stored groundwater and declining water levels, which can lead to increased costs of pumping in existing wells, deepening of existing wells, installation of new wells, decreased quality of drinking water, and reduction of flow and riparian habitat along the San Pedro River. Benson is the largest city in the area (fig. 1) and had a population of about 4,900 in 2005 (U.S. Census Bureau, 2006). The population of the area has grown moderately by a factor of about 1.5 during the past 20 years (Arizona Department of Water Resources, 2005; U.S. Census Bureau, 2006), but it is expected to increase more rapidly as residential developments are constructed for retirement communities or for satellite communities of nearby Tucson, Arizona.

Several entities, including the State of Arizona, the city of Benson, Cochise County, the public, and other interested parties, are concerned about the future availability and sustainability of the water supply in the middle San Pedro watershed. In 2005, the U.S. Geological Survey (USGS) began an investigation of the hydrology of the middle San Pedro watershed in cooperation with the Arizona Department of Water Resources (ADWR). This investigation is part of the Rural Watershed Initiative (RWI), a program established by the State of Arizona and managed by ADWR that focuses on water-supply issues in rural areas and encourages participation in local partnerships. Other RWI projects that were begun in 2005 by the USGS include investigations of the hydrology of Detrital, Mojave, and Hualapai basins in Mohave County in northwestern Arizona and of the Willcox and Douglas Basins in southeastern Arizona. RWI projects that were begun in 1999 by the USGS include studies of the hydrology of the Coconino Plateau in northern Arizona (Bills and others, 2007), the Mogollon Highlands in central Arizona (Parker and others, 2005), and the upper and middle Verde watershed in central Arizona (Blasch and others, 2006).

Effective management of the groundwater supply in the middle San Pedro watershed needs to be guided by a comprehensive understanding of the regional aquifers, surface-water bodies, and recharge and discharge processes. To obtain this understanding, the USGS and ADWR identified three work elements:

1. Refine the hydrogeologic framework;

2. Characterize the groundwater and surface-water system, recharge and discharge processes, and water quality in selected areas; and

3. Develop a predictive numerical groundwater-flow model for examining the potential groundwater and surfacewater responses to changes in recharge and discharge.

This report presents the results of element 1 . A hydrogeologic framework model (HFM) of the middle San Pedro watershed was developed to represent a new conceptual model of the spatial relations, extents, and thicknesses of hydrogeologic units (HGUs) that compose the aquifer system. The HGUs represent unconsolidated sediments and consolidated rocks that are significant for groundwater flow and occurrence. The HGUs are spatially extensive, and each HGU represents a unit that has similar geologic and water-bearing properties. The HFM provides a mechanism to systematically compile and visualize the geometry and spatial extent of the HGUs. The HGUs would be used in element 3 to develop a numerical groundwater-flow model of the middle San Pedro watershed.

\section{Purpose and Scope}

This report presents a synthesis by the USGS, in cooperation with the Arizona Department of Water Resources, of new and existing hydrogeologic and geophysical data for the middle San Pedro watershed in southeastern Arizona. The purpose of the report is to describe features of the hydrogeologic framework of the middle San Pedro watershed that are most important for developing groundwater-flow models that can be used to help manage water resources in the area. This report includes: (1) a description of the hydrogeologic setting and depositional history of basin fill sediments that form the primary aquifer system, (2) description of the stratigraphic and hydrogeologic units (HGUs) that compose the hydrogeologic framework, (3) updated bedrock altitudes underlying basin fill sediments using gravity and subsurface density models, (4) delineation of the stratigraphic units into HGUs in the basin fill on the basis of hydrologic and geophysical properties, and (5) a digital three-dimensional (3D) hydrogeologic framework model (HFM) that represents spatial extents and thicknesses of the HGUs.

Descriptions of the hydrogeologic framework include a review of the hydrologic and geophysical characteristics of the stratigraphic units within the aquifer from previous reports, a summary of existing well logs and geophysical logs, and a new 3D digital HFM of the aquifer system that describes the spatial extent and thicknesses of the HGUs. Discussion of 
bedrock altitudes includes a summary of interpretations of new and existing gravity data, bedrock densities from geophysical logs, major faults and areas of shallow bedrock, and the results of a subsurface density model of the gravity data. Descriptions of the distribution of fine- and coarse-grained basin fill alluvium in the basin fill include a summary of subsurface electrical properties from logs and an airborne transient electromagnetic survey.

This report is the first of three planned USGS reports on the hydrology of the middle San Pedro watershed, and describes the results of the first work element identified by ADWR and the USGS. The second planned report would describe the groundwater and surface water system, water budget, and water quality in selected areas (second element). The third planned report would describe a numerical groundwater-flow model that simulates new conceptualizations of the groundwater-flow system (third element).

\section{Physical Setting}

The middle San Pedro watershed comprises the northern portion of the Upper San Pedro Basin and the southern portion of the Lower San Pedro Basin (fig. 1). The Upper and Lower San Pedro Basins are northwest-southeast trending structural basins in Cochise, Pima, and Graham Counties in southeastern Arizona. The Upper and Lower San Pedro Basins are separated near the streamflow-gaging station San Pedro River near Benson, Arizona (09471800) (fig. 1), at areas of exposed bedrock at The Narrows, north of Benson (fig. 2). The southern boundary of the study area coincides with the northern boundary of the Sierra Vista subwatershed and the streamflowgaging station near Tombstone (San Pedro River near Tombstone, Arizona, 09471550). The northern boundary of the study area coincides with the streamflow-gaging station near Redington (San Pedro River at Redington Bridge, near Redington, 09472050). The western and eastern boundaries coincide with the surface-water divides of the Upper and Lower San Pedro Basins. For this report, the portion of the study area within the Upper San Pedro Basin is called the Benson subarea and the area within the Lower San Pedro Basin is called the Narrows-Redington subarea.

The San Pedro Riparian National Conservation Area (SPRNCA) extends from the Sierra Vista subwatershed to the southern part of the study area. The SPRNCA is managed by the Bureau of Land Management and was established in 1988 by Congress to protect the riparian ecosystem along the San Pedro River. The SPRNCA extends about $60 \mathrm{~km}$, from the international border north to St. David. The northernmost $14 \mathrm{~km}$ of the SPRNCA are within the Benson subarea.

\section{Physiography}

The middle San Pedro watershed is within the Basin and Range province of Fenneman (1931) and is characterized by rugged, subparallel mountain ranges trending generally north-northwest that are separated by eroded desert floor underlain by Cenozoic fill (Dickinson, 1991; Anderson and others, 1992). The area of the middle San Pedro watershed is about $3,500 \mathrm{~km}^{2}$ and it lies in a north-trending structural trough that extends from south of the international border with Mexico to several $\mathrm{km}$ beyond the confluence of the Gila River. About half the land surface is bedrock of the mountains that form the east and west sides of the basin and in isolated outcrops near the intermittent San Pedro River that roughly bisects the basin (fig. 2). The study area is about $110 \mathrm{~km}$ long in the north-south direction, and sedimentary deposits that compose the basin fill and valley floor average about 16 $\mathrm{km}$ wide and range from about 1 to $25 \mathrm{~km}$ wide. The valley floor, which is predominantly an erosional surface, generally slopes upward both to the east and west from the San Pedro River. Elevations of the valley floor range from about 880 to $1,500 \mathrm{~m}$, and elevations of the surrounding mountains range from about 1,500 to $2,650 \mathrm{~m}$.

The San Pedro River (fig. 1) drains the study area and flows from its origins in Mexico north to the Gila River north of the study area. The river is intermittent from the southern boundary of the study area to St. David (about $21 \mathrm{~km}$ ) and is ephemeral from St. David to the northern boundary at Redington (about $84 \mathrm{~km}$ ). All the tributaries to the river are ephemeral, incised less than $10 \mathrm{~m}$, and generally flow at right angles to the river. In the Benson subarea, the river valley is about $40-50 \mathrm{~km}$ wide and the basin slopes moderately upward to mountain elevations of about 2,000 $\mathrm{m}$ on the west and 2,100 m on the east. In the Narrows-Redington subarea, the river valley is about $30-40 \mathrm{~km}$ wide and the basin slopes steeply upward to mountain elevations of about 2,600 $\mathrm{m}$ on the west and 2,300 $m$ on the east.

\section{Acknowledgments}

The authors thank many landowners that permitted land access and installation of hydrologic monitoring equipment. This study would lack essential data without their help and support. The authors are grateful to Leslie Graser, Bill Remick, Tom Whitmer, and John Fortune of the Arizona Department of Water Resources for their technical guidance throughout the study. Ross Groom and Laura Davis of Petros Eikon Inc. modeled the airborne TEM data collected by Fugro Airborne Surveys. Ben K. Sternberg and the Geophysics Field Camp of The University of Arizona Department of Mining and Geological Engineering conducted geophysical surveys near The Narrows, Pomerene, and St. David. The Community Watershed Alliance provided a forum for discussing technical aspects of the study. Barbara Clark and David Harris of The Nature Conservancy helped obtain land access for installation of monitoring equipment. Kathleen McHugh, Eric Roudebush, and Leo Leonhart of Hargis+Associates, Inc., provided well inventories and geophysical surveys and logs. Mark McGowan, John Whittier, Daniel Weber, and Mark Cross of Errol L. Montgomery \& Associates provided aquifer-test data 


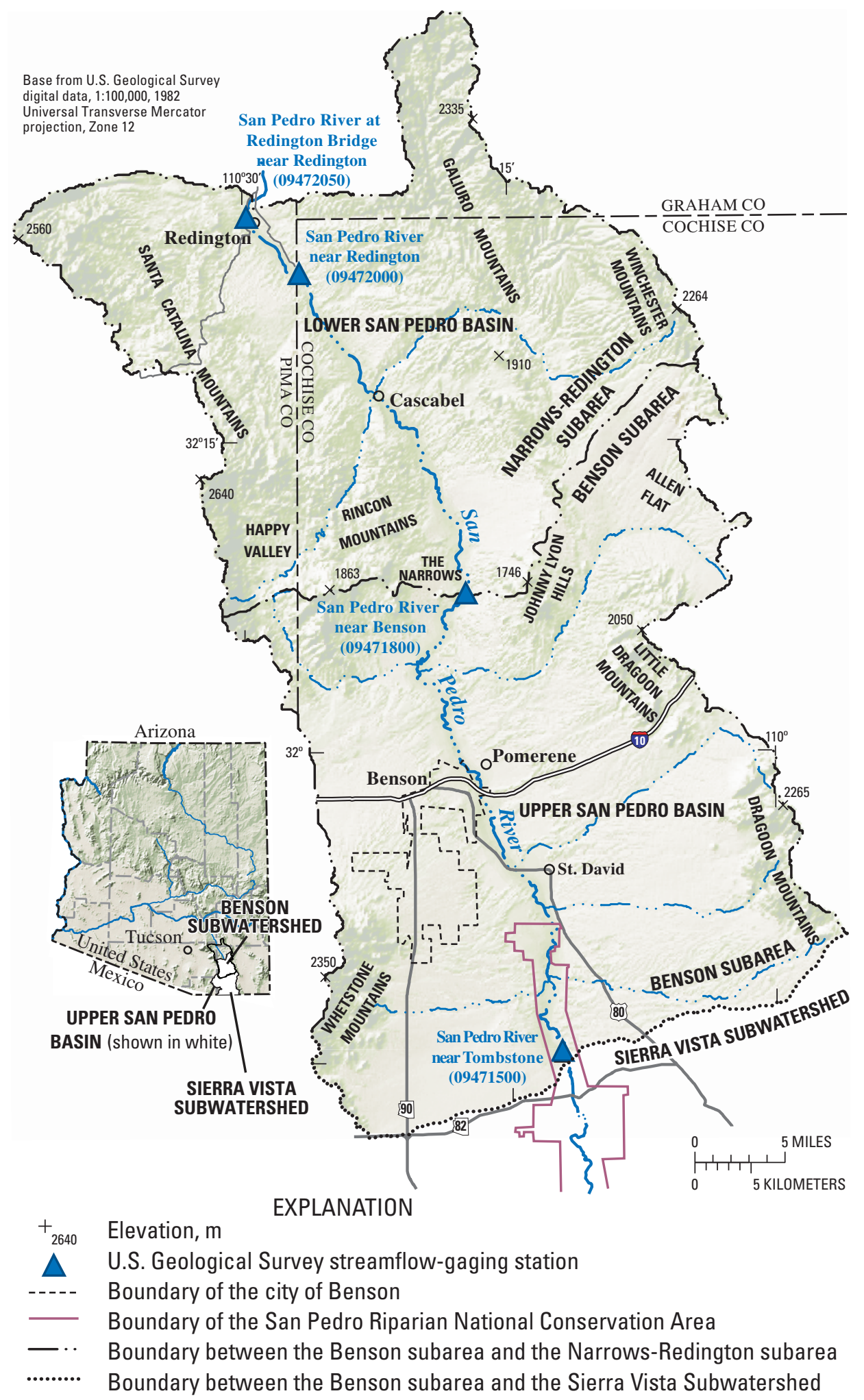

Figure 1. Map showing the middle San Pedro watershed, in southeastern Arizona. The boundary between the Benson and Narrows-Redington subareas, which passes through The Narrows, coincides with the boundary between the Upper and Lower San Pedro Basins. 
and geophysical well logs and helped to obtain land access. Nathan Dieterich of the Bureau of Land Management provided drill logs for wells in the SPRNCA.

\section{Methods of Investigation}

The hydrogeologic framework for the middle San Pedro watershed was investigated using a combination of analysis and modeling of existing and new geologic and geophysical data to infer the spatial extent and hydraulic properties of hydrogeologic units. An extensive literature search of published and unpublished hydrogeologic information was used to develop initial conceptual models and identify data needs. Preexisting data are available from drill logs for about 1,350 wells, geophysical logs for 4 wells (Daniel Weber, Errol L. Montgomery \& Associates, written commun., 2009), and from many regional geologic studies (Melton, 1965; Gray, 1967; Scarborough and Peirce, 1978; Shafiqullah and others, 1980; Drewes, 1981; Haynes, 1987; Menges and Pearthree, 1989; Scarborough, 1989; Dickinson, 1991; Hereford, 1993; Smith, 1994; Saltus and Jachens, 1995; Dickinson, 2003) and hydrogeologic studies (Brown and others, 1966; Freethey, 1982; Anderson and others, 1992; Jahnke, 1994; Corell and others, 1996; Pool and Coes, 1999; Goode and Maddock, 2000; Leenhouts and others, 2006; Coes and Pool, 2007; Pool and Dickinson, 2007).

Data needs included geophysical data for modeling subsurface structures that affect groundwater flow, depth to bedrock and thickness of saturated sediments, extents and depths of silt and clay layers within coarse-grained basin fill, and the extent and thickness of stream alluvium along the San Pedro River. To address these data needs, new data collection included airborne transient electromagnetic (TEM) surveys, surface and borehole geophysical surveys, gravity surveys, examination of drill cuttings, and basic geologic reconnaissance mapping. Geophysical data types collected for mapping subsurface structures, silt and clay layers, and stream alluvium include seismic refraction, magnetic soundings, controlled-source audiomagnetotellurics (CSAMT), borehole electrical resistivity and sonic velocity, airborne and groundbased TEM, and relative gravity measurements. CSAMT and airborne, ground-based, and borehole TEM methods measure electrical resistivity of the subsurface, which is a measure of the ability of the earth to resist the flow of electrical current. Electrical-resistivity values obtained from airborne TEM surveys were used to delineate areas of saturated silt and clay from saturated sand and gravel and to identify the extent of thick sequences of silt and clay layers within the basin fill along the main axis of the Benson subarea. Seismic refraction data were collected to delineate subsurface layers and structures that transmit pressure waves at faster velocities than overlying sediments. Seismic refraction was used to locate shallow crystalline rocks near bedrock outcrops at The Narrows. Relative gravity measures differences in the acceleration of gravity related to variations of the depth of crystalline and sedimentary rocks having higher density than overlying sediments. Relative gravity methods were used to constrain subsurface-density models of Bouguer gravity anomalies to identify bedrock structures and depths to the bedrock that underlies less dense basin fill sediments.

The HFM was constructed to describe spatial relations between bedrock and permeable and less permeable basin fill sediments. The HFM was developed using the results of the geologic and geophysical modeling and synthesizes the data into a single framework. The HFM was constructed using ESRI ${ }^{\circledR}$ GIS and Earthvision ${ }^{\circledR}$ software and data from geologic maps, driller reports, geophysical surveys, and subsurface density models.

\section{Hydrogeologic Setting}

Geologic exposures and relations in the study area reveal a complex tectonic and depositional history that is described by previous investigations (fig. 2) (Scarborough and Peirce, 1978; Shafiqullah and others, 1980; Drewes, 1981; Dickinson, 1991). The present geography of southeastern Arizona is mainly the result of extensional forces of the basin-and-range disturbance during Oligocene through Pliocene time (Scarborough and Peirce, 1978; Shafiqullah and others, 1980). Steeply dipping north- to northwest-trending faults resulted in fault-block mountains that are separated by structural troughs. The basin-fill alluvium that has been deposited in the structural troughs forms the major aquifers of southeastern Arizona and the middle San Pedro watershed (Anderson and others, 1992).

The hydrogeology is typical of many alluvial basins in the southwestern United States (fig. 3, table 1) (Anderson and others, 1992) and has been described by several reports (Brown and others, 1966; Roeske and Werrell, 1973; Pool and Coes, 1999; Coes and Pool, 2007; Pool and Dickinson, 2007). Groundwater flows through the basin fill aquifer from recharge areas near the mountains to perennial reaches of the San Pedro River, where it discharges to the stream and is transpired by phreatophytes (Pool and Coes, 1999). Rates and directions of groundwater flow are dependent on rates and distributions of recharge, discharge, and distributions of aquifer hydraulic properties. The volume of water in storage can be estimated by the distribution of specific yield (drainable porosity), which can be described as the portion of water stored in pores that can be drained owing to reduced hydraulic head. Specific yield distributions depend on the silt and clay content of the alluvial aquifer, because water drains readily from pores spaces in coarse-grained deposits of sand and gravel but tends to be retained within the small pore spaces between grains of silt and clay. Therefore, estimates of the volume of stored groundwater depend not only on extents of the basin fill aquifer, but also depend on the distribution of fine-grained deposits of silt and clay. 


\section{Upper and Lower Basin Fill Depositional History}

The depositional history and resulting facies distributions within the upper and lower basin fill are primary controlling factors in the hydrologic properties of the hydrogeologic framework. The middle San Pedro watershed underwent episodes of deposition of basin fill alluvium separated by long intervals of erosion, channel incision, and soil formation (Morrison, 1985). The basin fill corresponding to these episodes is subdivided into Miocene-Pliocene lower basin fill, PliocenePleistocene upper basin fill, and Holocene stream alluvium.

\section{Miocene-Pliocene Lower Basin Fill}

The lower basin fill was deposited upon bedrock and older Tertiary sediments during the basin-and-range disturbance beginning in the mid to late Miocene (Scarborough and Peirce, 1978). Deposition occurred during the tectonically active period of basin-and-range disturbance into closed basins flanked by fault-block mountains. Deposition was followed by an extended period of erosion that removed an unknown volume of fill and caused retreat and pedimentation of the adjacent mountain fronts. The erosional event was regionally

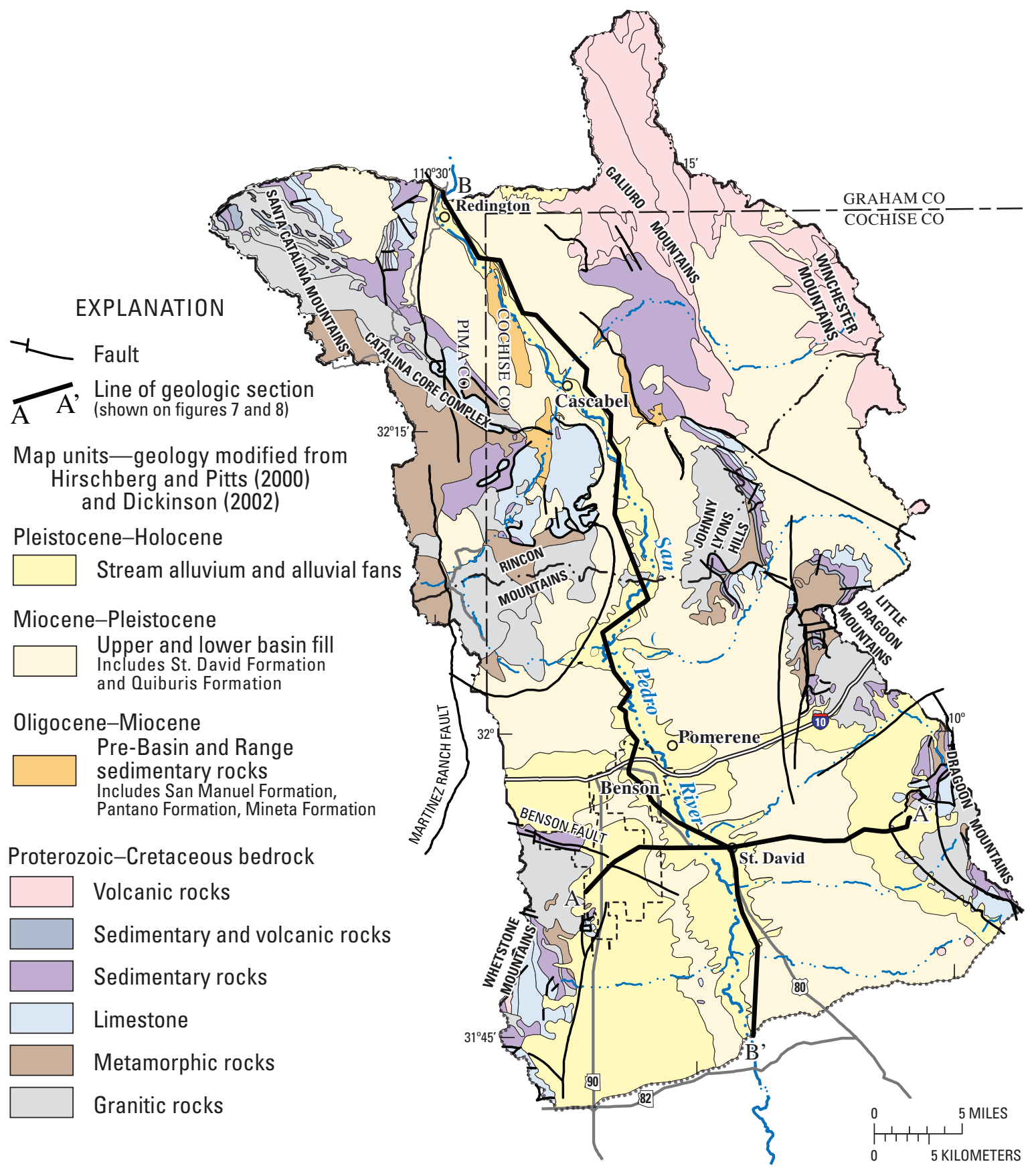

Figure 2. Generalized geologic map of the middle San Pedro watershed, southeastern Arizona. 
Table 1. Physical properties and ages of the stratigraphic units and hydrogeologic units in the middle San Pedro watershed, southeastern Arizona.

[--, not included]

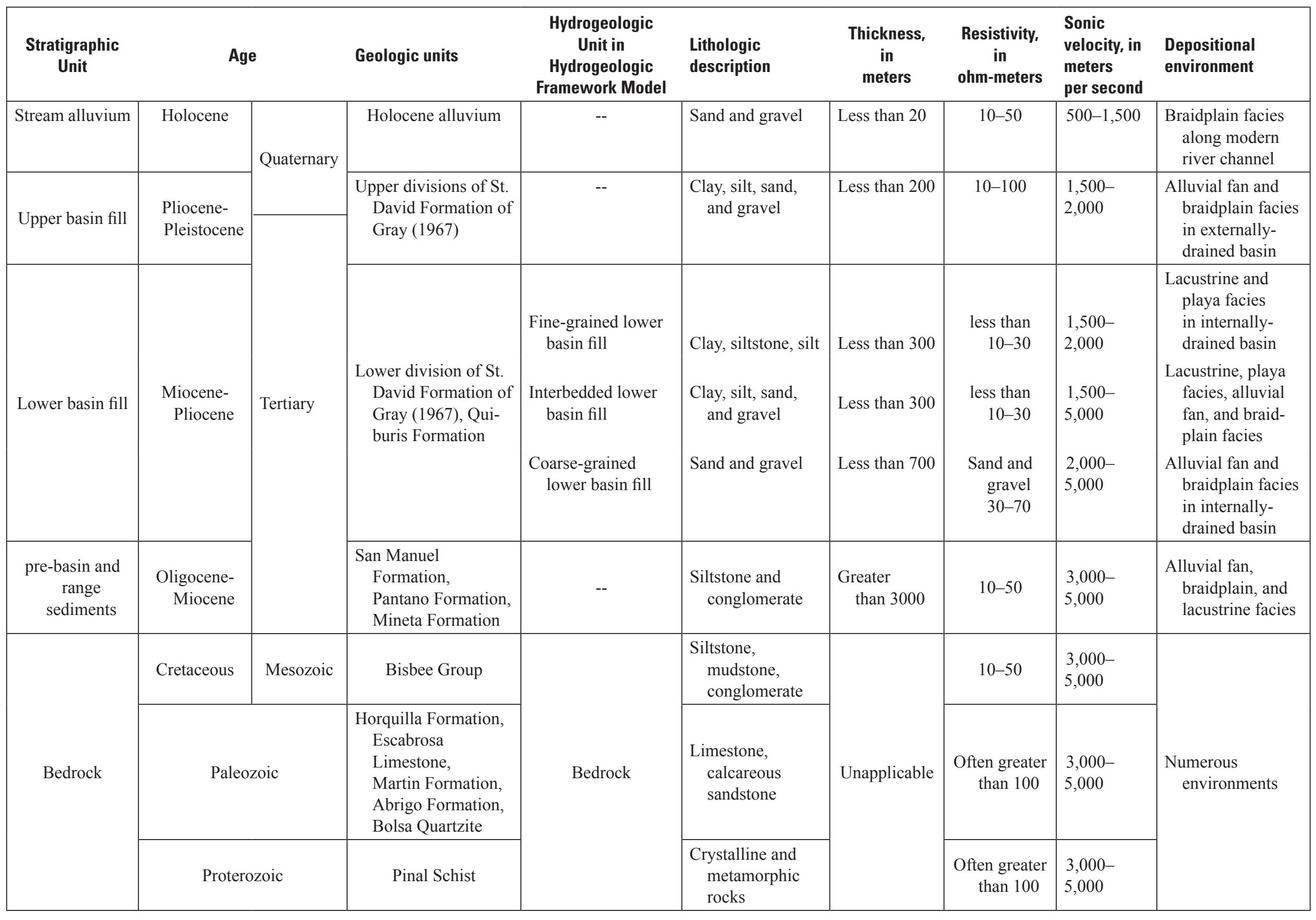


time-transgressive, occurring in southeastern Arizona over as much as $5 \mathrm{~m}$.y. from the end of the Miocene to the beginning of the Pleistocene (Melton, 1965; Morrison, 1985). The upper sections of the lower basin fill in the basin center of the Benson subarea are represented by the lowest fine-grained division of the St. David Formation, which is dominated by red clays (Gray, 1967). In the Narrows-Redington subarea, the lower basin fill is represented by the Quiburis Formation, which is exposed owing to Pliocene-Quaternary dissection by the San Pedro River (Ladd, 1975; Dickinson, 2003). The Quiburis Formation consists of fluviolacustrine sandy silts that increase in coarseness to alluvial fan and braidplain facies toward the valley margins and abundant diatomite beds that increase in thickness northward. Unlike the St. David Formation, the Quiburis Formation contains few clay beds in the study area, but it contains extensive lacustrine facies downstream north of the study area (Dickinson, 2003).

\section{Pliocene-Pleistocene Upper Basin Fill}

Upper basin fill represents the depositional period after the integration of the Gila River drainage system across southeastern Arizona. The upper basin fill primarily is represented in the study area by the middle and upper divisions of the St. David Formation (Gray, 1967), which occupies a $40-\mathrm{km}$ reach of the San Pedro River from The Narrows to about $8 \mathrm{~km}$ south of the town of St. David. The St. David Formation is not present downstream from The Narrows (Gray, 1967). The St. David Formation is well exposed in the Benson-St. David area, where it forms prominent terraces as much as $200 \mathrm{~m}$ above the channel of the San Pedro River (Gray, 1967). In the middle division of the St. David Formation, red beds are interlayered with white, chalky freshwater limestones, green clays, brown silts, and light gray pyroclastic units. The upper division is characterized by brown, tan, or orange silts, silty clays, and fine sands separated by paleosols and caliche. Although coarser grained sediments become more prevalent in the upper division, interlayered beds of brown and red clays are not uncommon. Clay-size particles are prevalent through the St. David Formation and predominant in the lower and middle divisions, where they constitute 80 percent of the former and 50-60 percent of the latter. The upper division contains about $25-35$ percent claysized particles (Gray, 1967).

The end of St. David Formation deposition marked the cessation of a lacustrine-fluvial environment and the integration the San Pedro River with the Gila River drainage system. The drop in base level and the establishment of a through-flowing stream initiated a period of extensive erosion and channel incision that included removal of much of the upper member of the St. David Formation (Melton, 1965; Gray, 1967). A mid-Pleistocene erosional surface is mantled with alluvial gravels, called the "gravel wash" by Gray (1967) and "pediment gravels" by Morrison (1985) that is as much as $30 \mathrm{~m}$ thick where it fills channels cut into the St. David Formation.

\section{Late Pleistocene-Holocene Stream Alluvium}

Most work on the late Pleistocene-Holocene alluvial history of the San Pedro River has been conducted upstream from the town of St. David, mainly above the southern boundary of the study area. Working in Curry Draw west of Lewis Springs, Haynes (1981) used radiocarbon dating to define the chronology of a sequence of alluvial deposits that record a number of episodes of channel aggradation and degradation from more than 45,000 years ago to historical times. The oldest alluvium, which is older than the 45,000-year range of carbon-14 dating, was deposited in channels incised into the St. David Formation. Subsequent erosion of this unit led to formation of numerous springs along San Pedro River tributaries that formed clay and marl marsh deposits between 30,000 and 13,000 years ago. Desiccation of the marsh deposits between 13,000 and 11,000 years led to their erosion, followed by deposition of channel sands. Then, between 11,000 and 9,000 years ago, deposits of a black, organic-rich clay filled the channels again, preserving some artifacts of early hunters belonging to the Clovis culture (Haynes, 1981).

The first period of Holocene channel entrenchment occurred about 7,000 years ago, as recorded in poorly sorted alluvium filling deep channels. That episode was followed by at least four more episodes of channel filling and entrenchment before the historical arroyo formation that began in the 1880s (Haynes, 1981). Whether these episodes of Holocene arroyo formation and burial occurred more or less synchronously throughout the Upper San Pedro Basin has not been established. Hereford (1993) investigated historical channel processes in the San Pedro River from the community of Hereford to Clifford Wash near the southern boundary of the study area. He identified a preentrenchment alluvium that was inset into the St. David Formation. He believed this to be correlative with the McCool alluvium described by Haynes $(1981,1987)$ that was deposited over a period of time beginning about A.D. 1450 and continuing until the formation of the modern arroyo. The timing of onset of arroyo formation is not precisely known. Within the reach studied by Hereford (1993), channel incision began sometime after 1890 and had migrated almost $30 \mathrm{~km}$ upstream less than 18 years later. Within the middle San Pedro watershed, the modern channel is entrenched as much as $6 \mathrm{~m}$ in the reach north of The Narrows. Arroyo inception in the San Pedro River most likely began in the late 19th or early 20th century, as it did in other entrenched streams throughout the western United States (Cooke and Reeves, 1976).

Postentrenchment alluvium includes all channel, floodplain, and terrace deposits inset into the arroyo of the San Pedro River. Working upstream from St. David, Hereford (1993) described four postentrenchment depositional units inset $1-10 \mathrm{~m}$ below the preentrenchment surface. These units included two terraces and two flood plains above the active channel and below the top of the arroyo walls that bound the postentrenchment channel system. Judging from aerial photographs, most postentrenchment deposits appear to have formed after 1937; however, the highest inset terrace had 
been emplaced, stabilized, and become vegetated by that time and an incipient, lower, younger terrace was visible. The two flood-plain units are present in a number of places above the active channel. The older flood plain is inset about $1 \mathrm{~m}$ below the lowest terrace, and deposits are as much as $2 \mathrm{~m}$ thick. The younger flood plain is inset beneath the older one less than $1 \mathrm{~m}$. Both flood-plain units are composed mainly of mediumto coarse-grained sand with lenses of granule to pebble-size gravel. The older flood plain was not visible in 1937 aerial photographs but does appear in 1955 aerial photos, and the younger flood plain was first visible in aerial photos of 1970 (Hereford, 1993). One or more of these depositional units may be missing in various reaches along the San Pedro River. No detailed study of postentrenchment alluvium has been conducted in that part of the middle San Pedro watershed downstream from St. David.

\section{Hydrogeologic Framework}

A conceptual model of the hydrogeologic framework of the San Pedro Basin comprises stratigraphic units and structural features that influence groundwater flow. The stratigraphic units consist of undifferentiated bedrock, pre-basin-and-range sediments, lower basin fill, upper basin fill, and stream alluvium. The 3D framework model includes a division of the lower basin fill into coarse- and fine-grained HGUs. The spatial distribution of the fine- and coarse-grained HGUs is inferred from models of the subsurface electrical resistivity distribution measured during the airborne TEM survey. The pre-basin-andrange sediments, however, are not included as an HGU owing to insufficient subsurface data needed to define the spatial extent of the sediments. Structural features in the hydrogeologic framework include areas of shallow bedrock that results in relatively thin basin fill and areas of deep bedrock associated with thick basin fill. The subsurface features were defined by the subsurface density models of the gravity data.

\section{Bedrock}

Crystalline rocks, limestone, and clastic rocks ranging in age from Precambrian to Cenozoic form the mountains and underlying bedrock that bound the basin (figs. 2, 3) (Drewes, 1981; Dickinson, 1991). These rocks have been subjected to extensive tectonic deformation, including mid-Tertiary lowangle extensional tectonics that resulted in extensive faulting and rotation (Eberly and Stanley, 1978; Scarborough and Peirce, 1978; Shafiqullah and others, 1980; Dickinson, 1991). The undifferentiated bedrock is not an important aquifer, with the exception of the Paleozoic limestone, which is locally an important aquifer.

\section{Pre-Basin-and-Range Sedimentary Rocks}

Tertiary sedimentary rocks deposited before the basinand-range disturbance may be minor aquifers along the margins of the basins and underlie the basin-fill sediments. The sedimentary rocks include the Mineta Formation (Clay,

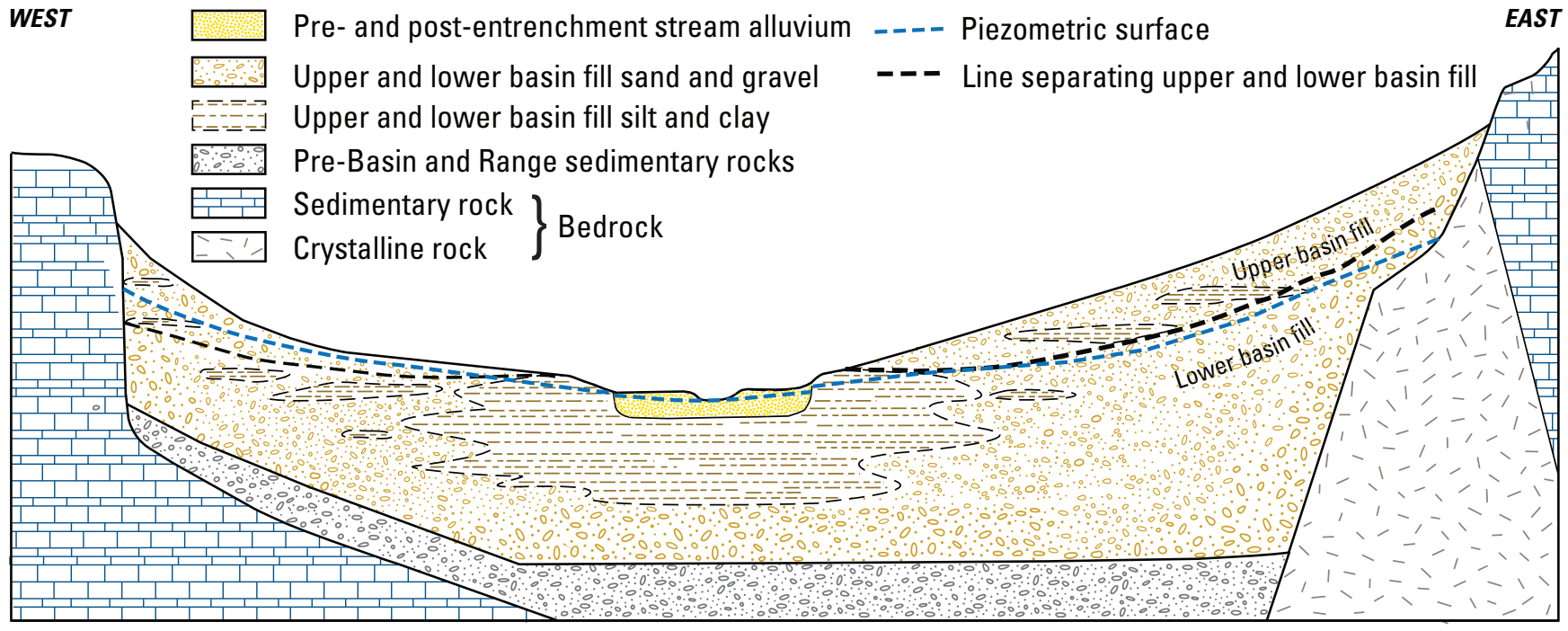

Figure 3. Generalized east-west section and stratigraphic units in the middle San Pedro watershed, southeastern Arizona. The east-west width of the watershed is about $40 \mathrm{~km}$ in the Benson subarea and $15 \mathrm{~km}$ in the Narrows-Redington subarea. Total thickness of the basin fill sediments is about $1,000 \mathrm{~m}$ or less. 
1970), Pantano Formation (Brown and others, 1966; Finnell, 1970; Balcer, 1984), San Manuel Formation (Dickinson, 1991), and Teran basin beds (also called the Mineta Formation by Grover (1984)). Except for sediments of the San Manuel Formation, these fluvial and lacustrine strata were deposited in local basins before mid-Tertiary volcanism and were derived from the uplifted Catalina-Rincon metamorphic core complex to the west of the Narrows-Redington subarea (Scarborough, 1989). The San Manuel Formation is exposed in three areas near Cascabel and contains volcaniclastics mainly derived from the Galiuro Volcanics. Pre-basin-and-range sediments have been subjected to mid-Tertiary extensional tectonics related to the basin-and-range disturbance (Eberly and Stanley, 1978; Scarborough and Peirce, 1978; Shafiqullah and others, 1980; Dickinson, 1991). Hydrologic properties of these units are generally unknown owing to paucity of data, but they are likely to be relatively impermeable. In the Upper San Pedro Basin near Sierra Vista, the Pantano Formation may be an important water-bearing unit where fractured, but it is generally of low permeability owing to cementation (Pool and Dickinson, 2007).

\section{Basin Fill}

Basin fill comprises a sequence of unconsolidated to moderately well consolidated alluvial sediments of Late Tertiary and Quaternary age derived from erosion of uplifted mountain blocks. The basin fill aquifer is greater than $1,000 \mathrm{~m}$ thick in some areas and is bounded laterally and at depth by relatively impermeable crystalline rocks of pre-Tertiary age, Paleozoic limestone, Mesozoic sandstone and mudstone, and Tertiary prebasin sediments (Pool and Coes, 1999). Basin fill was deposited during and following the waning phases of mid-Tertiary extensional tectonics. Drainage patterns and lateral extents of depositional systems indicate gradations from a coarse-grained facies of sand and gravel at the basin margins and at depth to a fine-grained facies of silt and clay in the basin center. The basin fill can be divided into lower and upper parts on the basis of geologic logs, drill logs, and physical-property variations that are evident in geophysical logs (Pool and Coes, 1999; table 1). The lower basin fill forms the primary aquifer and the upper basin fill is unsaturated in most areas.

\section{Lower Basin Fill}

Sediments of the lower basin fill generally include poorly cemented gravel and sand at the basin margins and silt, clay, and some evaporates at the basin center (fig. 3). Lower basin fill is distinguished from upper basin fill in well logs by greater consolidation, higher density, higher sonic velocity, and fewer fine-grained interbeds. The coarse-grained facies of lower basin fill is commonly described in drill logs as conglomerate or decomposed granite, whereas the fine-grained facies of lower basin fill includes gypsum and few sand and gravel interbeds. The fine-grained facies is represented by the lowest division of the St. David Formation (Gray, 1967), and forms a confining bed that divides the basin fill into deep and shallow aquifers in the central part of the study area. The confining bed varies considerably in thickness and areal extent - ranging from more than $300 \mathrm{~m}$ in thickness near the basin center to nonexistent along the basin margins. Thus, groundwater flow is complex in the study area, and the flow characteristics are substantially affected by the location and properties of the confining bed.

\section{Upper Basin Fill}

The upper basin fill unit lies unconformably upon the lower basin fill and typically contains a variety of alluvial fan and fluviolacustrine sediments and sand and gravel interbeds. The upper basin fill is considerably thinner than the lower basin fill. The upper basin fill lies above the water table across much of the basin. However, local areas of saturated upper basin fill are hydrologically important because the deposit can be much more permeable than lower basin fill.

\section{Stream Alluvium}

A narrow and thin stringer of highly permeable stream alluvium is incised into the basin fill along the major stream channels (fig. 3) (Hereford, 1993; Pool and Coes, 1999). The stream alluvium is an important local aquifer that drains the basin fill aquifer, receives streamflow infiltration, and stores water that supports riparian vegetation during periods lacking runoff (Pool and Coes, 1999).

\section{Basin Fill Textural Distribution}

\section{Airborne TEM Surveys}

Airborne TEM surveys were used to identify the boundary between basin-fill sediments and impermeable crystalline rocks, and to map thick fine-grained deposits within coarsergrained deposits in the basin fill (fig. 4). The airborne TEM surveys were flown by Fugro Airborne Surveys in 2006 using the GEOTEM system (Annan and Lockwood, 1991). In the Benson subarea, the surveys consisted of $489 \mathrm{~km}$ of approximately north-south lines ( 25 degrees west of north, parallel to the long axis of the basin), $111 \mathrm{~km}$ of east-west cross lines, and 2 lines $(27 \mathrm{~km})$ at 10 degrees east of north (fig. 4). Near The Narrows, the surveys consisted of $245 \mathrm{~km}$ of north-south lines. Depth of investigation of the surveys was 100 to $300 \mathrm{~m}$. The GEOTEM system consists of a transmitter on an airplane towing a 3-coil receiver. The system transmits a periodic (30 $\mathrm{Hz}$ ) magnetic field with a waveform that is a half-sine current 
pulse of $4.045 \mathrm{msec}$. The transmitter is offset from the receiver approximately $132 \mathrm{~m}$ horizontally and $39 \mathrm{~m}$ vertically, which theoretically provides better depth resolution than a colocated transmitter and receiver.

One-dimensional (1D) models of electrical resistivity versus depth derived from the airborne and ground-based TEM data were developed by Petros Eikon in Toronto, Canada, to map subsurface electrical resistivity (Dickinson and others, in press). The 1D resistivity models were calibrated at several locations on the basis of drill-log control and ground-based TEM surveys using EMIGMA software from Petros Eikon, Inc. The 1D models comprise six horizontal layers having uniform electrical resistivity.

\section{Subsurface Electrical Properties}

Electrical properties of the subsurface are known from borehole geophysical logs and previous electrical surveys in the nearby Sierra Vista subwatershed (Pool and Coes, 1999; Fleming and others, 2002; Wynn, 2006) (fig. 5, table 1). Relations between lithology and electrical properties from two geophysical logs near Benson were the basis for the lithologic interpretation of GEOTEM surveys. Unsaturated sediments can be highly resistive - greater than $100 \mathrm{ohm}-\mathrm{m}$ in many cases. Saturated basin fill tends to be much less resistive, ranging from less than $10 \mathrm{ohm}-\mathrm{m}$ for clay-rich intervals to more than $50 \mathrm{ohm}-\mathrm{m}$ for sand and gravel intervals that include minor clay (fig. 6, wells D-17-20 31AAB and D-17-20 33DCC). Older rocks such as limestone and relatively impermeable granite and metamorphics are also generally more resistive than saturated alluvial sediments - greater than $100 \mathrm{ohm}-\mathrm{m}$. However, lowpermeability sedimentary rocks of Mesozoic and older Tertiary age can be electrically indistinguishable from basin fill. Surface geology, borehole geologic logs, or other geophysical information are needed to distinguish basin fill from these older finegrained sedimentary rocks. Regardless of the inability to distinguish older sediments from basin fill using available data, low resistivity values are indicative of poor aquifers or poor quality water that is not suitable for most supply needs. Groundwater quality in the study area is generally good, less than $500 \mathrm{mg} / \mathrm{L}$ total dissolved solids (TDS), with the exception of the extreme southwest part of the area, where some marginal water quality, about 1,500 mg/L TDS, has been identified (Coes and others, 1999). Therefore, low resistivity values of $10 \mathrm{ohm}-\mathrm{m}$ or less generally indicate fine-grained sediments and poor aquifers in the study area, or high salinity in the southwestern part.

\section{Spatial Distribution of Electrical Resistivity}

Two-dimensional (2D) grids of the resistivity values (250 $\mathrm{m}$ by $250 \mathrm{~m}$ ) generated from the 1D models along flight lines using a 2D natural neighbor interpolation scheme show an estimated spatial distribution of resistivity between flight lines (fig. 4). Inputs for the interpolation were resistivity values from each 1D model within 10-m thick vertical intervals that span the entire TEM survey. The resistivity value assigned to each cell in the 2D grid was calculated as the arithmetic mean of resistivity values within each 10 -m interval. For horizontal positions having multiple resistivity model data at 10-m intervals, the arithmetic means of the modeled resistivity values were inputs to the interpolation. Three-dimensional (3D) resistivity distributions were constructed by vertically stacking each $2 \mathrm{D}$ resistivity grid. Data inputs for each interpolation consist of resistivity values from each 1D model within 10-m thick vertical intervals that span the entire TEM survey from altitudes of $-100 \mathrm{~m}$ to $1,390 \mathrm{~m}$ (vertical datum NAVD 88). Interpolations were limited to resistivity values within the altitude of saturated materials on the basis of water levels measured in wells in 2006. A rectangular gap near Benson was left out of the interpolation because the TEM survey was not done in this area in order to avoid conductive manmade structures that distort the electrical response.

Interpolated resistivity values from the 1D models vary within broad and continuous areas of low and high values that generally align along the regional trend of mountain ranges and basins (fig. 4). Resistivity values are mainly restricted to basin fill, but some values are available for bounding bedrock outcrops. Lower values range from less than $10 \mathrm{ohm}-\mathrm{m}$ near the central north-south axis of the basin, and larger values greater than $500 \mathrm{ohm}-\mathrm{m}$ occur near bedrock outcrops at the basin margins and at The Narrows (fig. 4).

Areas of low resistivity values, from less than 10 to 30 ohm-m, between altitudes of 990 and 1,000 m (fig. 4) are common along three major areas. Such an area underlies much of the lowest land-surface elevations within the central part of the basin and extends northward from areas of high resistivity near GEOTEM east-west line 38040 to another area of high resistivity south of The Narrows. This central area may be continuous across the data gap near Benson. A region of low resistivity in the southwestern part of the study area, visible at the western end of line 38030 , coincides with an area having salinity greater than $500 \mathrm{ppm}$, which may contribute to lower electrical resistivity in saturated sediments. Another area of low resistivity was mapped at the western end of line 38060 (fig. 4). This area is at higher land-surface elevations and may indicate conductive bedrock near the land surface; it appears to indicate a feature that is discontinuous from the central area.

Areas with larger resistivity values are near small mapped outcrops of Paleozoic sedimentary and limestone rocks that are surrounded by basin fill, south of line 38030 (fig. 4). Resistivity values between 30 and $100 \mathrm{ohm}-\mathrm{m}$ occur near and to the east of the small outcrops. Additional areas with values of 30-100 ohm-m occur within a broad area between the large data gap near the cities of Benson and Pomerene and the Dragoon Mountains, and also along the Whetstone Mountains. High salinity measured at two wells $(1,250$ and $651 \mathrm{mg} / \mathrm{L})$ in the southwestern areas may contribute to low resistivity values. 


\section{EXPLANATION}

${ }^{38060}$ Airborne TEM flight line and flight line number

Interpolated electrical resistivity values from 1-D models at depth of $200 \mathrm{~m}$, in ohm-m

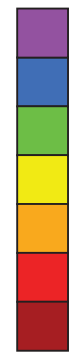

Less than 10

$10-20$

20-30

$30-50$

$50-100$

$100-500$

Greater than 500

Map units-geology modified from

Hirschberg and Pitts (2000) and Dickinson (2002)

Pleistocene-Holocene

Stream alluvium and alluvial fans

Miocene-Pleistocene

Upper and lower basin fill Includes St. David Formation and Quiburis Formation

Oligocene-Miocene

Pre-Basin and Range sedimentary rocks Includes San Manuel Formation, Pantano Formation, Mineta Formation

Proterozoic-Cretaceous bedrock

\section{Volcanic rocks}

Sedimentary and volcanic rocks

Sedimentary rocks

Limestone

Metamorphic rocks

Granitic rocks

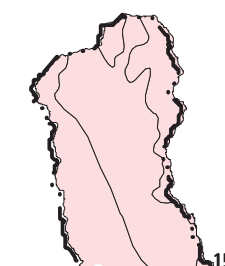

(1) 


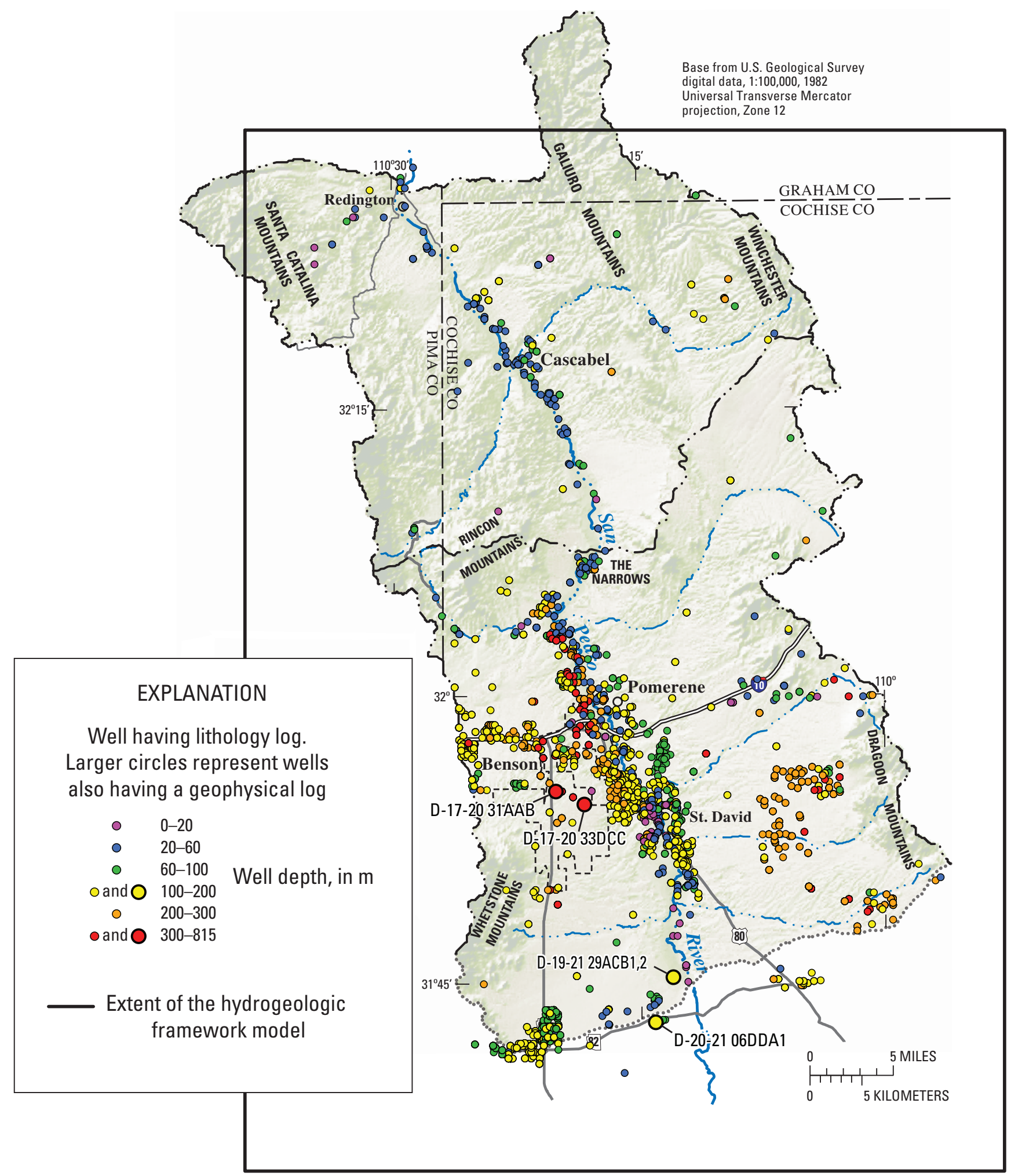

Figure 5. Locations of wells with geophysical logs and drill logs used in construction of the hydrogeologic framework model and the extent of the hydrogeologic framework model. 


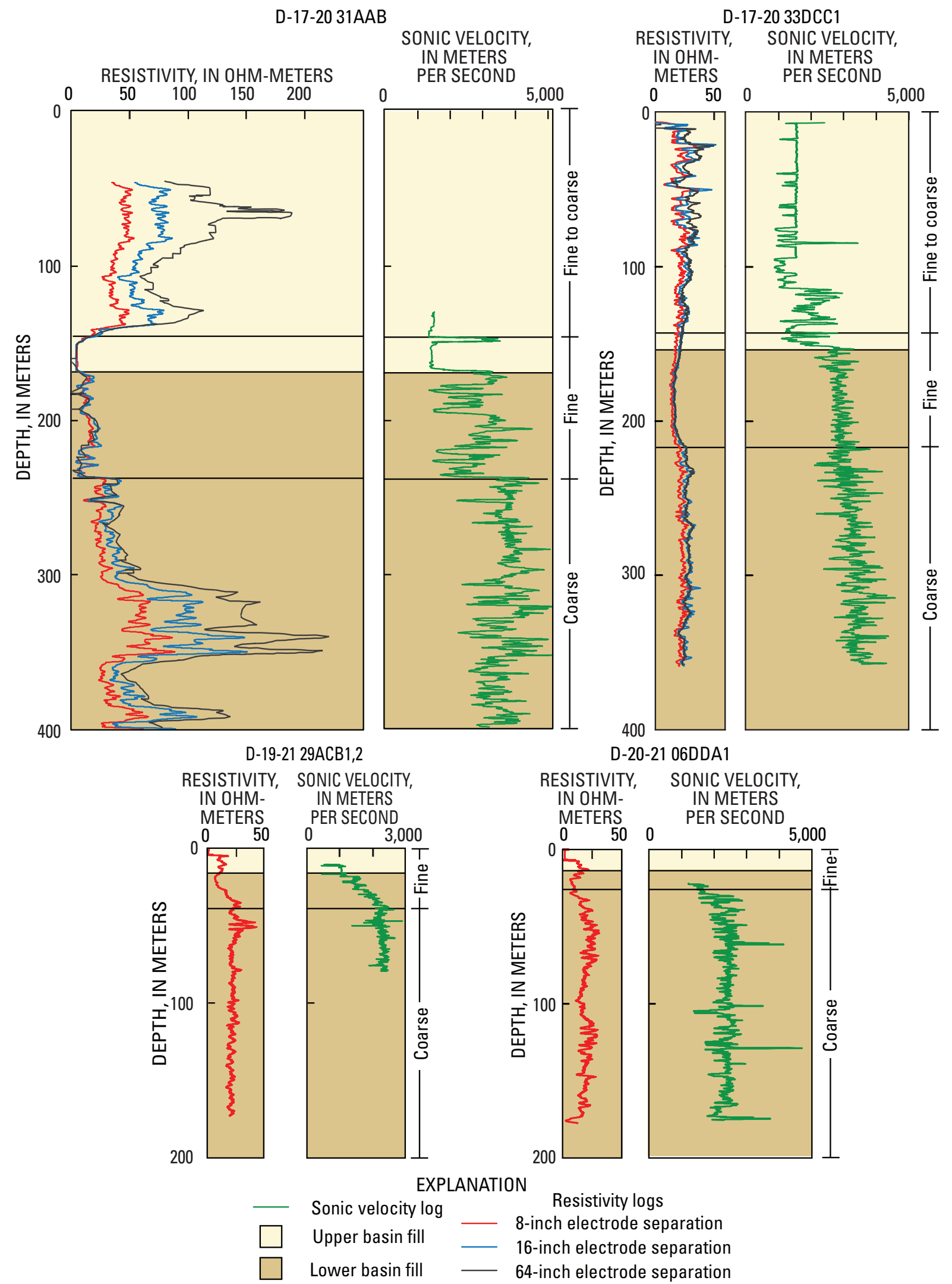

Figure 6. Depths of the top of the lower basin fill and fine-grained and coarse-grained facies in the middle San Pedro watershed indicated by electrical resistivity and sonic velocity logs from four wells. 


\section{Inferred Basin Fill Lithology from Electrical Resistivity Distribution}

Inferred lithology using resistivity and drill logs (figs. 7 and 8 , panels $A$ and $B$ ) ranges from crystalline bedrock and limestone on the basin margins to a thick sequence of basin fill, more than $300 \mathrm{~m}$, including an interval of silt and clay as thick as $200 \mathrm{~m}$, underlain by sand and gravel in the deepest part of the basin. The top and lateral distribution of the fine-grained facies in the basin center is indicated by a zone of resistivity values of $10 \mathrm{ohm}-\mathrm{m}$ or less and by drill logs. The fine-grained facies is bounded at the top and lateral margins by an interval of 10-30 ohm-m material that likely represents a gradation from the fine-grained facies to the surrounding coarse-grained facies of basin fill. A significant wedge of medium-grained basin fill is mapped by a wedge of material having resistivity of 10-50 ohm-m and overlies the finegrained basin fill east of the San Pedro River (fig. 7). Interpolated resistivity values compare favorably with the electric $\log$ at the well D-17-20 33DCC, where the saturated zone has values of 20-30 ohm-m in logs for wells D-17-20 31AAB and D-17-20 33DCC (fig. 6). A zone of 10-20 ohm-m resistivity at depths of about 170 to $210 \mathrm{~m}$ in the electric log likely represents the margin of the fine-grained facies that is evident as the thick interval of $10 \mathrm{ohm}-\mathrm{m}$ or less resistivity immediately east of the well and at the basin center.

\section{Bedrock Depth and Structures Affecting Groundwater Flow}

Subsurface geologic features, such as buried faults and areas of shallow bedrock, can result in spatially varying hydrologic flow properties of the subsurface. Faults can be a barrier to groundwater flow because of (1) juxtaposition of high- and low-permeability materials and (2) low-permeability material (fault gouge) in the fault zone owing to pulverization of rocks or deposition of minerals along the fault. Areas of shallow bedrock can affect groundwater flow because thin, permeable sediments overlying the bedrock are less transmissive than areas of thicker sediments of equivalent permeability. The amount of groundwater flow generally is reduced, resulting in increased groundwater levels on the upgradient side of the shallow bedrock.

Bedrock depth and subsurface structures in the middle San Pedro watershed have been investigated both in regional gravity studies and in more focused local studies. Regional studies include that of Oppenheimer and Sumner (1980), who constructed 2D profiles across alluvial basins throughout Arizona and then interpolated between profiles to produce a 3D depth-to-bedrock map. The study assumed that the average sediment density in a particular basin varies as a function of the gravity anomaly; larger anomalies were inferred to correspond with deeper basins and higher average densities. Density values ranged from about $2.04 \mathrm{~g} / \mathrm{cm}^{3}$ to $2.42 \mathrm{~g} / \mathrm{cm}^{3}$.
Saltus and Jachens (1995) constructed a depth-to-bedrock map across the entire Basin and Range Province using constant densities of $2.02 \mathrm{~g} / \mathrm{cm}^{3}, 2.12 \mathrm{~g} / \mathrm{cm}^{3}, 2.32 \mathrm{~g} / \mathrm{cm}^{3}$, and 2.42 $\mathrm{g} / \mathrm{cm}^{3}$ for depth intervals of 0-200 m, 200-600 m, 600-1,200 $\mathrm{m}$, and greater than $1,200 \mathrm{~m}$, respectively. The authors also accounted for low densities associated with Cenozoic volcanic rocks. Gettings and Houser (2000) developed subsurface models for the Sierra Vista area that included the mid-Tertiary Pantano Formation.

Likely the first gravity study to focus on the middle San Pedro watershed was that of Spangler (1968), who collected data at 360 stations in the Walnut Gulch Experimental Watershed. Spangler (1968) modeled a 1,000-m-thick sequence of alluvium in the Tombstone subbasin along a single two-dimensional profile using an alluvium density of $2.27 \mathrm{~g} / \mathrm{cm}^{3}$. Bankey and Kleinkopf (1982) collected data at 112 gravity stations in the Whetstone Mountains to evaluate mineral resource potential. No interpretation of the data was published, but those data are incorporated in the present study. Halvorson (1984) collected gravity data at 273 new stations in the San Pedro Valley. 2D models of the data were constructed using the same anomaly-density relationship presented by Oppenheimer and Sumner (1980). Halvorson (1984) modeled bedrock depths of about $800 \mathrm{~m}$ for the Huachuca City subbasin and about $700 \mathrm{~m}$ for the Tombstone subbasin. Schwartz (1990) measured gravity values at a station spacing of about 1 mile throughout the rugged, 214- $\mathrm{km}^{2}$ Galiuro Mountains. 2D models were constructed using field-measured density values of $2.43 \mathrm{~g} / \mathrm{cm}^{3}$ for volcanic rock and $2.16 \mathrm{~g} / \mathrm{cm}^{3}$ for alluvium. Schwartz (1990) investigated the internal structure of the Galiuro volcanic complex, and alluvium thickness in the basins bounding the mountain range was not estimated.

\section{Gravity Data Collection and Basin Gravity Anomaly}

Existing and newly collected gravity data were used to constrain the subsurface density model. New gravity data were collected at 266 stations in the study area (fig. 9) using Lacoste and Romberg D-127 and D-209 relative gravity meters. Existing gravity data were obtained from the Pan-American Center for Earth and Environmental Studies (PACES) dataset (PACES, 2008), which in turn is based largely on the National Oceanic and Atmospheric Administration (NOAA) National Geophysical Data Center (NGDC) Land and Marine Gravity Data compilation (Dater and others, 1999). Individual gravity surveys of the Whetstone Mountains (Bankey and Kleinkopf, 1982), San Pedro Valley (Halvorson, 1984), Galiuro Mountains (Schwartz, 1990), and Walnut Gulch Experimental Watershed (Spangler, 1968) contributed to most of the data available through PACES. Other sources of data obtained through PACES/NGDC data are from the Defense Mapping Agency Aerospace Center and the Arizona Gravity Data Base maintained at the University of Arizona in the 1970's and 1980's. 


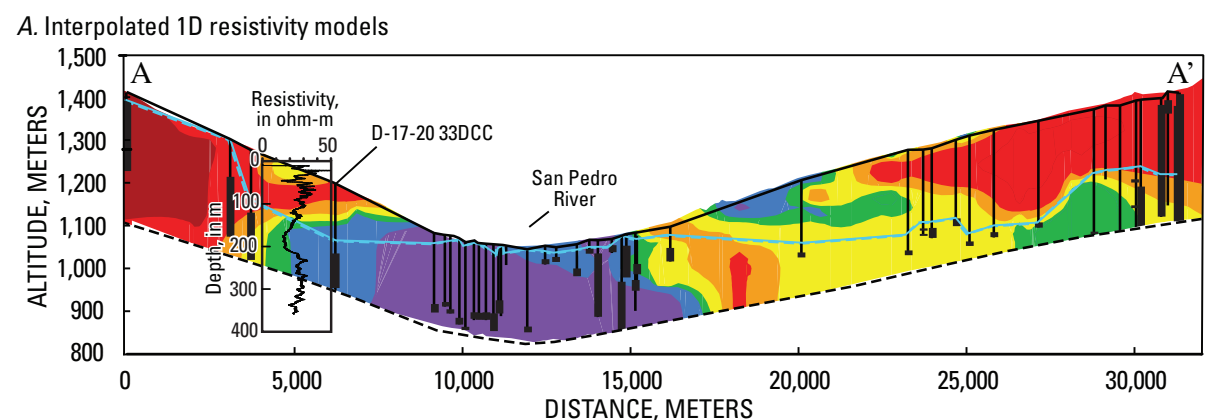

$B$. Hydrogeologic units based on interpolated resistivity and lithology from driller's logs

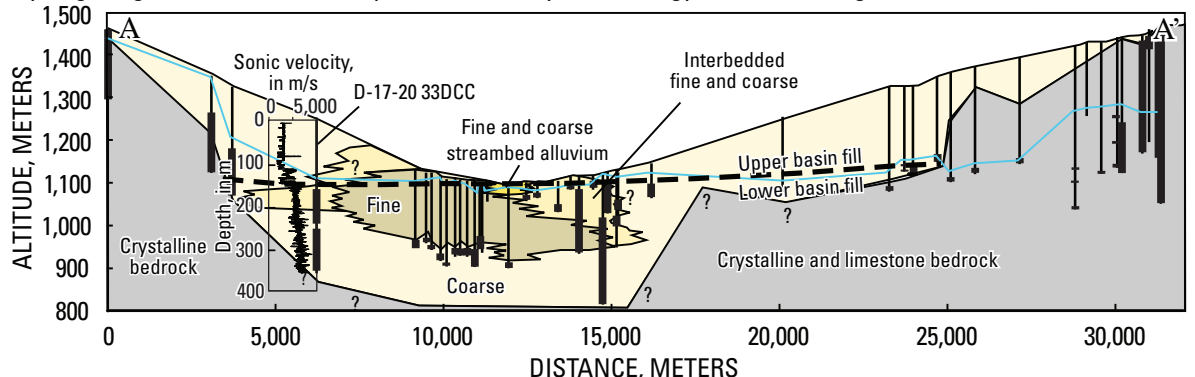

C. Hydrogeologic units in hydrogeologic framework model

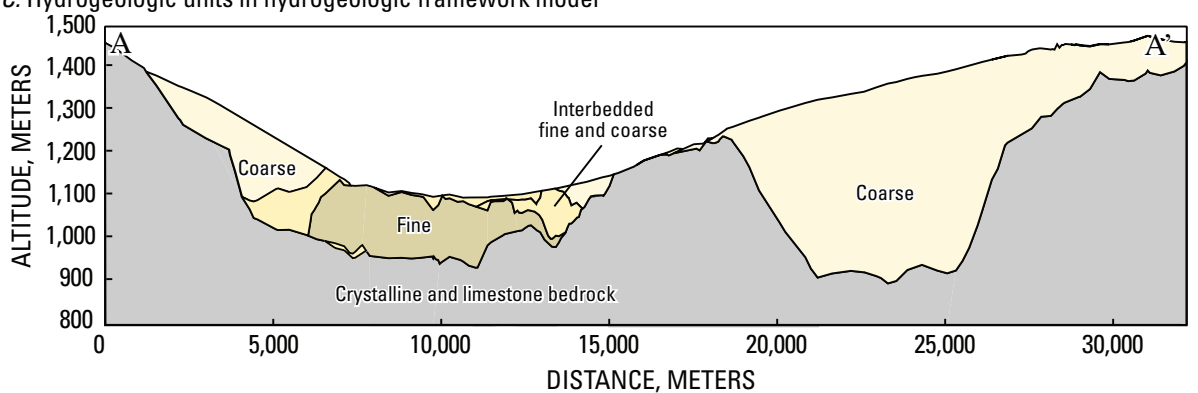

$D$. Groundwater model layering based on hydrogeologic units

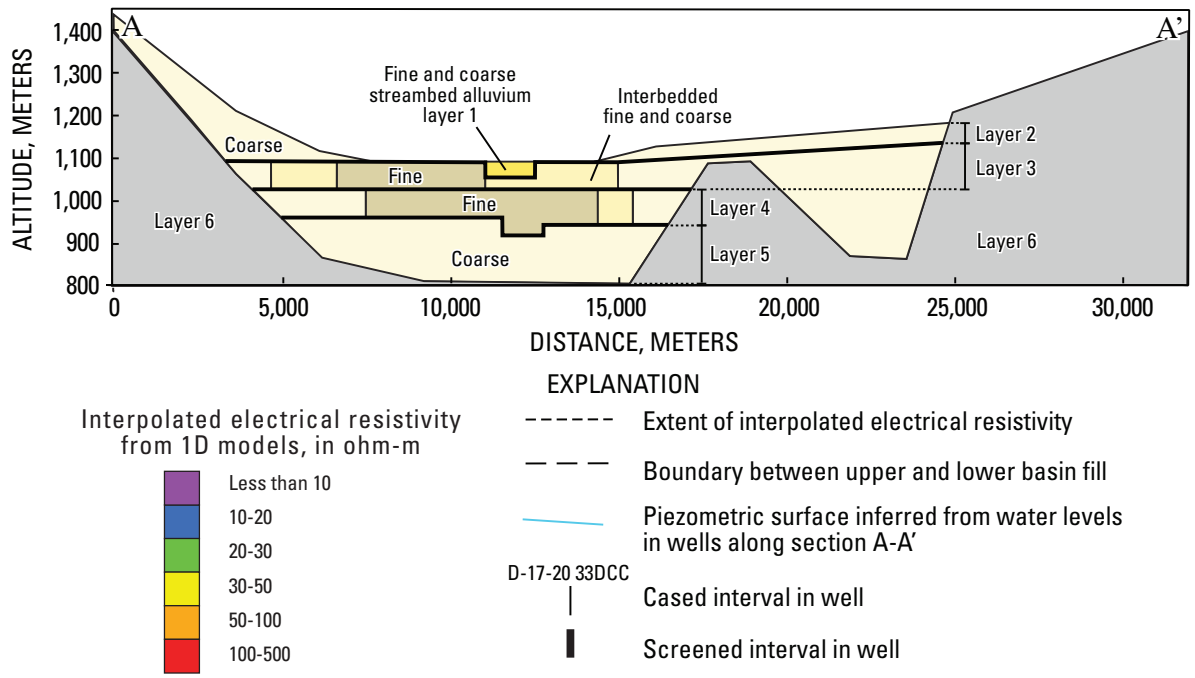

Figure 7. Section A-A' (fig.2) showing a stratigraphic interpretation on the basis of geophysical and lithologic data. $A$, Interpolated one-dimensional electrical-resistivity models from the land surface to $200 \mathrm{~m}$ depth in the center of the section, and $300 \mathrm{~m}$ elsewhere. $B$, Interpreted hydrogeologic units using electrical resistivity and lithology from driller's logs. C, Section within the digital hydrogeologic framework model. $D$, Possible configuration of hydrogeologic zones and layers for a numerical groundwaterflow model. The interpolated resistivity values and the resistivity log at well D-17-20 33DCC indicate similar sequences of resistivity values. The sonic velocity log at well D-17-20 33DCC and the lithologic descriptions from driller's logs indicate a possible boundary between the upper and lower basin fill. 
$A$. Interpolated $1 \mathrm{D}$ resistivity models

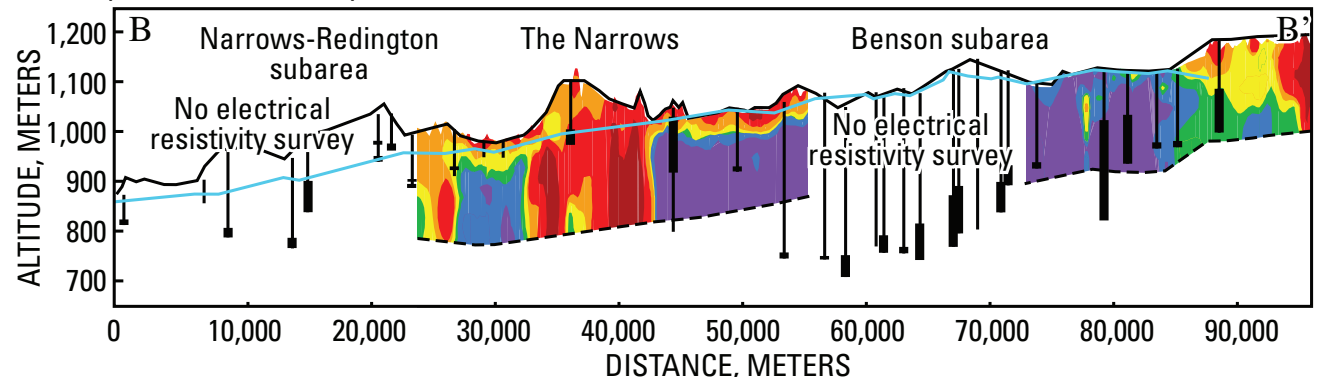

$B$. Hydrogeologic units based on interpolated resistivity and lithology from driller's logs

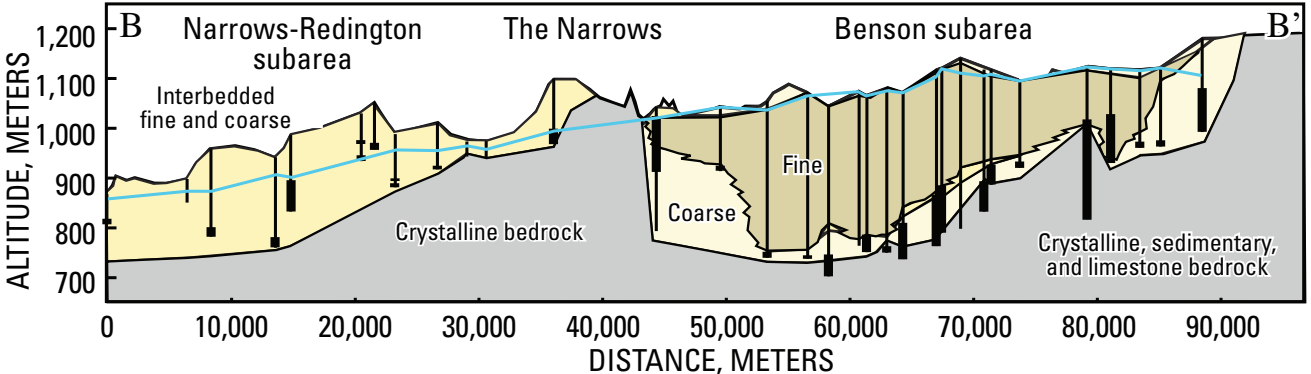

C. Hydrogeologic units in hydrogeologic framework model

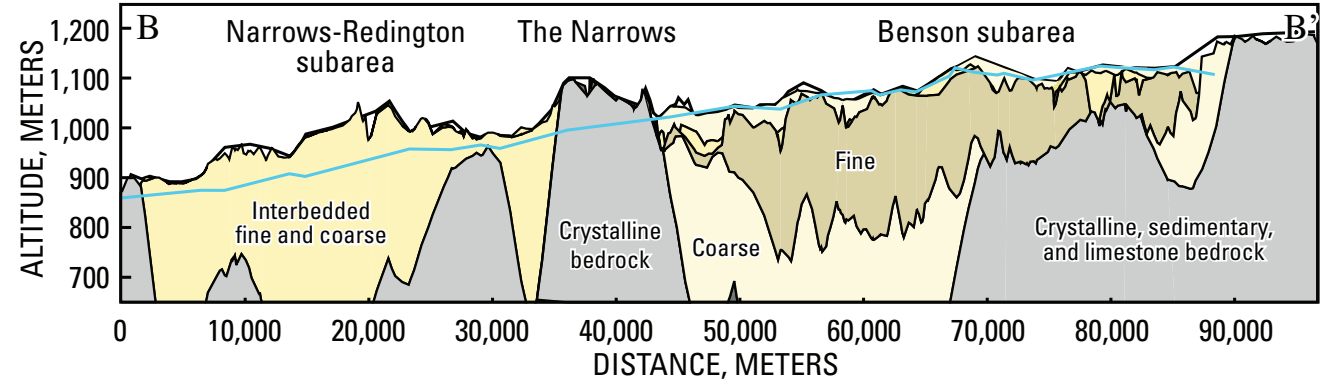

$D$. Groundwater model layering based on hydrogeologic units

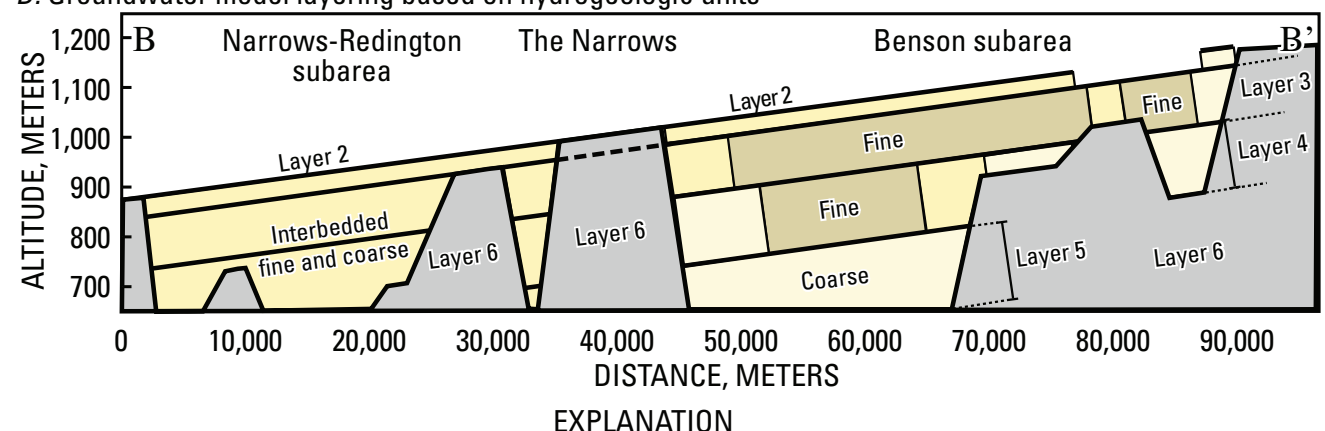

Interpolated electrical resistivity from 1D models, in ohm-m

Less than 10
$10-20$
$20-30$
$30-50$
$50-100$
$100-500$

----- Extent of interpolated electrical resistivity

Piezometric surface inferred from water levels in wells along section B-B'

Cased interval in well

\. Screened interval in well

$100-500$

Figure 8. Section B-B' (fig.2) showing a stratigraphic interpretation on the basis of geophysical and lithologic data. $A$, Interpolated one-dimensional electrical-resistivity models from the land surface to $200 \mathrm{~m}$ depth in the center of the section, and $300 \mathrm{~m}$ elsewhere. $B$, Interpreted lithology using electrical resistivity. $C$, Section within the digital hydrogeologic framework model. $D$, Possible configuration of hydrogeologic zones and layers for a numerical groundwater-flow model. 
In compiling the initial NGDC gravity dataset (later incorporated into the PACES dataset), quality control procedures were maintained by NOAA to remove outliers and poor data. All data were made consistent with the IGSN71 gravity datum. To verify the compatibility of the PACES data with data newly collected for this study, an A10 absolute gravimeter by Micro-g Lacoste, Inc. was used to establish new absolute gravity benchmarks near gravity stations in the PACES dataset. Although direct comparison is difficult because the PACES and A10 stations are not exactly coincident (the A10 stations were located on existing benchmarks for ease of measurement), the measurements agree to within $1 \mathrm{mGal}$. Data retrieved from PACES in NAD27 and NGVD29 elevation datums were converted to NAD83 and GRS80 datums. Only the measured gravity values from PACES were used; free-air, Bouguer, and terrain corrections were performed independently for this study.

The complete Bouguer gravity anomaly (CBA) represents the departure from the expected gravitational field at a given latitude, land surface elevation, and surrounding terrain, assuming a constant subsurface density. Differences from the expected gravitational field are caused primarily by heterogeneities in subsurface density. To calculate the CBA, gravity data were corrected using the International Gravity Formula based on the GRS80 ellipsoid, a free-air correction with a vertical gradient of $0.3086 \mathrm{mGal} / \mathrm{m}$, a Bouguer slab correction with a density of $2.67 \mathrm{~g} / \mathrm{cm}^{3}$, and a Bullard B spherical cap correction (LaFehr, 1991). Terrain corrections were carried to a distance of $167 \mathrm{~km}$ from each station using a combination of methods described by Kane (1962) and Nagy (1966). The CBA data were gridded using a minimum curvature algorithm.

The CBA includes the cumulative effect of all subsurface density heterogeneities. To isolate anomaly features caused only by low-density basin fill, density contrasts caused by isostatic compensation and nonuniform bedrock density were removed. Isostatic compensation was modeled using the Airy root model (Simpson and others, 1983), assuming a depth of sea level compensation of $30 \mathrm{~km}$ and a Moho density contrast of $0.33 \mathrm{~g} / \mathrm{cm}^{3}$. The gravitational response of the isostatic compensation, ranging from about $-100 \mathrm{mGal}$ in the northwest corner of the study area to -123 $\mathrm{mGal}$ in the southeast corner, was subtracted from the CBA to create the isostatic residual anomaly.

To remove the effect of nonuniform bedrock density, a gridded basement anomaly for the Basin and Range Province, representing the gravitational effect of pre-Cenozoic formations and calculated using an iterative procedure from gravity stations located on pre-Cenozoic outcrops (Saltus and Jachens, 1995), was subtracted from the isostatic residual anomaly to create the basin gravity anomaly (fig. 9). Because the procedure to produce the basement gravity anomaly is dependent on an estimation of the depth-density relation in Cenozoic sedimentary fill, the basin gravity anomaly would differ somewhat if a different depth-density relation were used. However, 2D modeling of the isostatic residual anomaly suggests that the influence of the depth-density relation is minimal and the basement gravity surface would differ only slightly if a different relation were used. A number of Cenozoic rock formations in the study area are not incorporated in calculating the basement gravity anomaly. These include volcanic rocks in the Galiuro Mountains, volcanic rocks east of Tombstone (but not Cretaceous volcanic rocks west and north of Tombstone), and crystalline rocks in the Dragoon Mountains.

The basin gravity anomaly (fig. 9) includes the effects of both low-density basin fill deposits and low-density Cenozoic volcanic rocks, but it also reflects errors in data collection and assumptions made in the previous steps. Areas of exposed basement rocks are uniformly near zero $\mathrm{mGal}$, indicating that the density used for these areas $\left(2.67 \mathrm{~g} / \mathrm{cm}^{3}\right)$ in the Bouguer and terrain corrections was appropriate. Areas mapped as basin fill alluvium show negative gravity anomalies.

\section{Subsurface Density}

Subsurface density contrasts between bedrock and basin fill sediments were estimated using borehole gamma-gamma density logs and sonic velocity logs (fig. 10). Density was estimated from the sonic velocity logs by using a polynomial expression of the Nafe-Drake curve (Brocher, 2005). The borehole gamma-gamma density logs are from three wells in the Sierra Vista subwatershed, and the sonic velocity logs are from two wells about $6 \mathrm{~km}$ southwest of Benson and two wells near the San Pedro River $25 \mathrm{~km}$ south of Benson.

Density values increase at greater depths in logged intervals in upper basin fill and are nearly uniform in lower basin fill (fig. 10). The lower basin fill is at about $30 \mathrm{~m}$ depth in wells D-19-21 29ACB2 and D-20-21 06DDA1. Above $30 \mathrm{~m}$, density values increase rapidly with greater depth, varying from less than $1.5 \mathrm{~g} / \mathrm{cm}^{3}$ at a depth of $12 \mathrm{~m}$ to $2.2 \mathrm{~g} / \mathrm{cm}^{3}$ at a depth of 30 $\mathrm{m}$. Density values are uniformly about $2.2 \mathrm{~g} / \mathrm{cm}^{3}$ below $30-\mathrm{m}$ depth. Similarly, density values in logged intervals of wells D-17-20 31BAA and D-17-20 33DCC are nearly uniform, 2.2 to $2.3 \mathrm{~g} / \mathrm{cm}^{3}$, below depths of $140 \mathrm{~m}$ and $160 \mathrm{~m}$, respectively. Density values in logged intervals in wells TW3, D-21-20 11BCD, and D-21-20 13CBB1 increase throughout the interval, varying from $2.1 \mathrm{~g} / \mathrm{cm}^{3}$ to $2.3 \mathrm{~g} / \mathrm{cm}^{3}$ between depths of $65 \mathrm{~m}$ and $170 \mathrm{~m}$. Based on these data, a variable depth-density relationship was calculated for the upper basin fill (fig. 10).

\section{Subsurface Density Modeling}

A 3D subsurface density model was constructed to simulate the basin gravity anomaly. To interpret the gravity anomaly, a surface-based Fourier transform method (Parker, 1972) was used to estimate depth to bedrock through iterative inverse modeling. In this method, one or more surfaces, rather than discrete volumes, are used to denote density contrasts. This method is well suited for modeling sedimentary basin depths in the Basin and Range Province, where the contrast between basin fill and basement rocks is distinct and continuous (Saltus and Jachens, 1995). The gravitational response of 


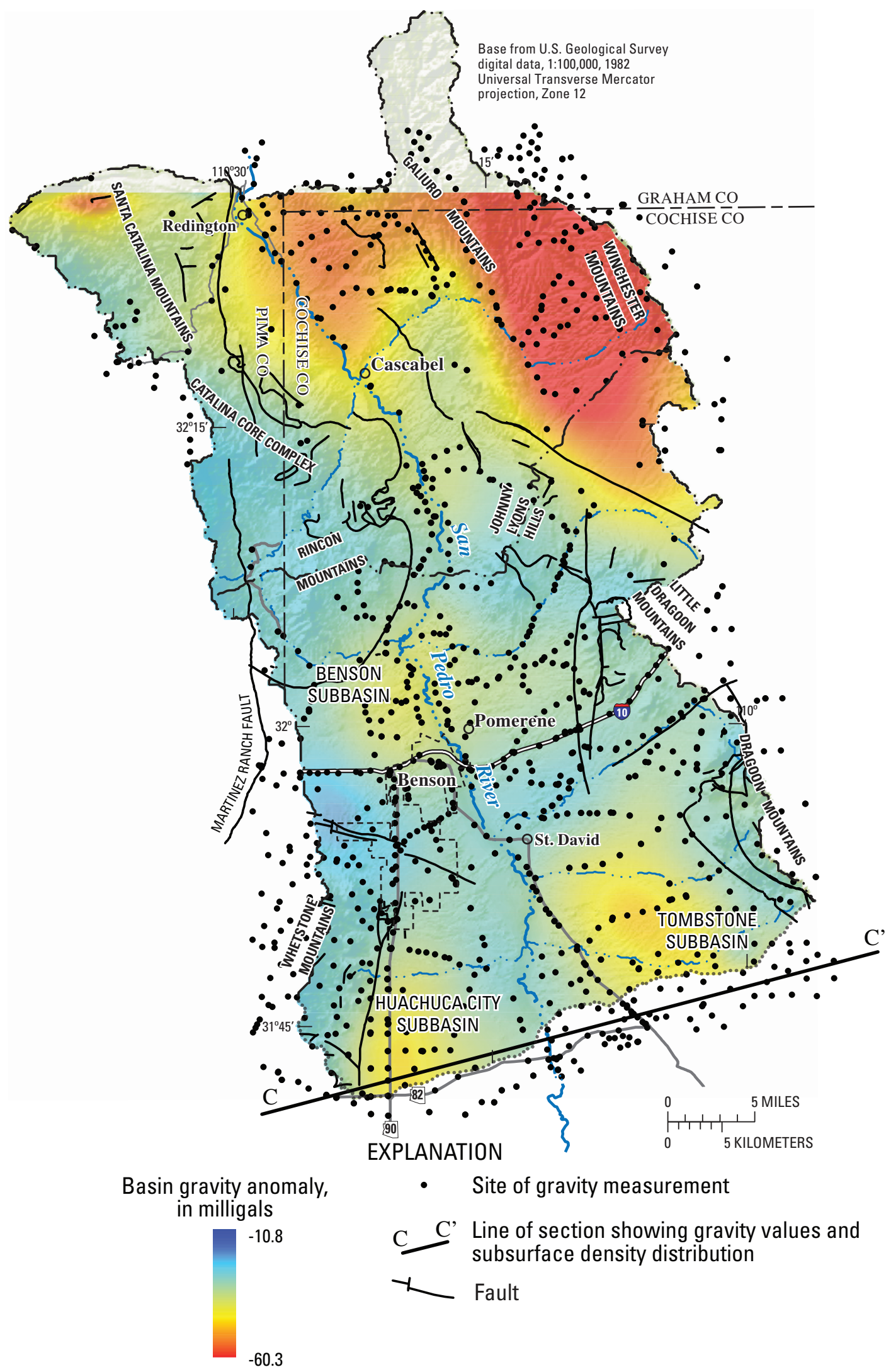

Figure 9. Sites of gravity measurements and derived gravity anomaly used to estimate bedrock altitude in the middle San Pedro watershed, southeastern Arizona. Section C-C' is shown on figure 11. 
subsurface density variations is calculated on a level surface; for comparison of modeled and measured gravity, the measured gravity must also be on a level surface. Therefore, the final residual was upward continued to a constant elevation of $3,000 \mathrm{~m}$, above the highest topography in the study area.

The subsurface density model includes six layers having uniform density values, which are assigned on the basis of geophysical logs (figs. 10,11). The density of sediments is $1.65 \mathrm{~g} / \mathrm{cm}^{3}$ from the land surface to $20 \mathrm{~m}$ depth. Between $20 \mathrm{~m}$ and $25 \mathrm{~m}$, density is $1.9 \mathrm{~g} / \mathrm{cm}^{3}$. From $25 \mathrm{~m}$ to $110 \mathrm{~m}$, density is $2.1 \mathrm{~g} / \mathrm{cm}^{3}$. From $110 \mathrm{~m}$ to $250 \mathrm{~m}$, density is $2.2 \mathrm{~g} / \mathrm{cm}^{3}$. Density is $2.3 \mathrm{~g} / \mathrm{cm}^{3}$ below $250 \mathrm{~m}$. The density of lower basin fill is assumed to be constant at $2.3 \mathrm{~g} / \mathrm{cm}^{3}$. Density of bedrock is $2.67 \mathrm{~g} / \mathrm{cm}^{3}$. Not all layers are present throughout the model.

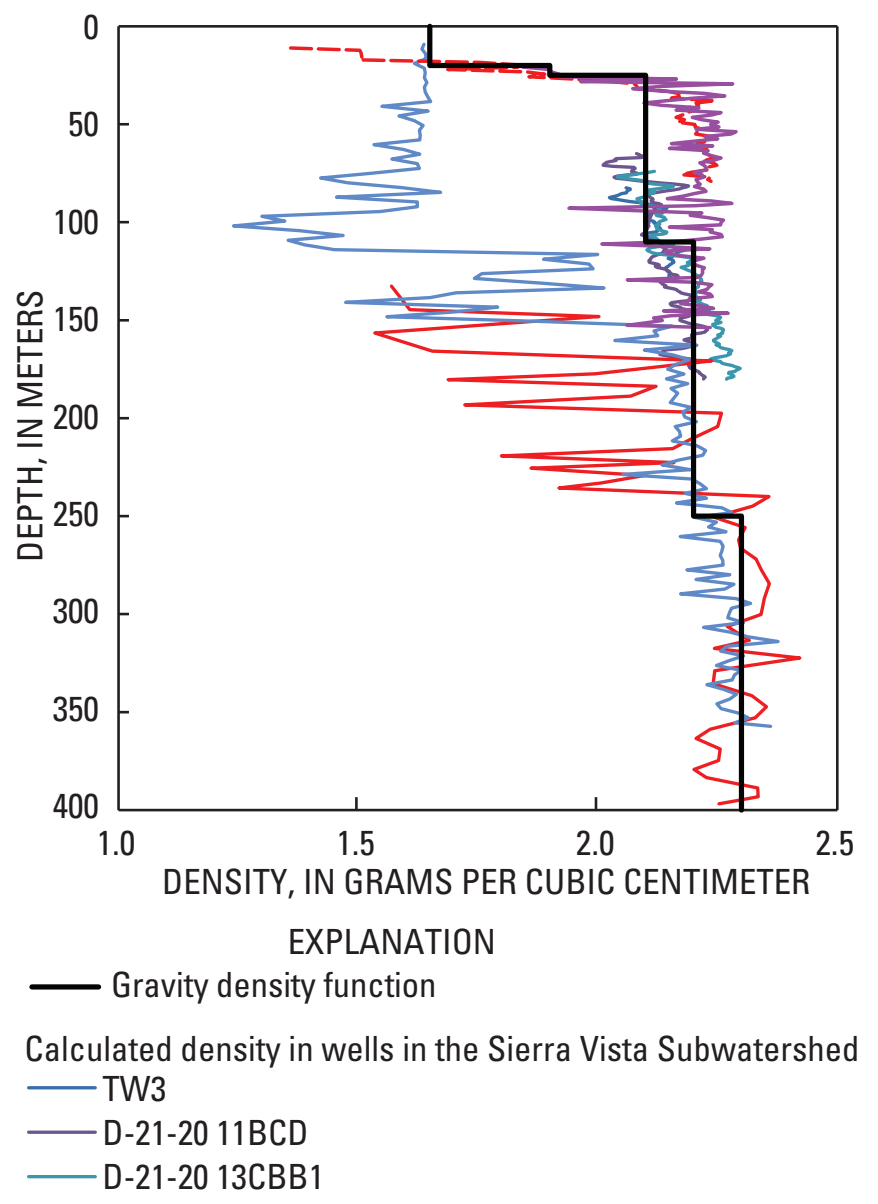

Calculated density in wells in the Benson subarea

-D-17-20 31BAA

D-17-20 33DCC

$---D-19-2129 A C B 2$

-D-20-21 06DDA1

Figure 10. Subsurface density profiles from wells and the gravity density function used to assign density of layers in the subsurface density model for the middle San Pedro watershed, southeastern Arizona.
The elevation of the top of lower basin fill is fixed, based on geophysical and driller's logs. Where lower basin fill is closer to the surface than $250 \mathrm{~m}$, it supersedes the presence of overlying layers. This occurs primarily at the basin margins, but also where bedrock is near the surface south of Benson. The upper two layers are generally present throughout the domain.

These density values are slightly less, particularly near the surface, than those used in a previous study of depth-tobedrock immediately south of the present study (Gettings and Houser, 2000), which used density values based primarily on a gamma-gamma log from well D-21-20 13CBB1. Lower density values used in this report result in more shallow bedrock depths than those described by Gettings and Houser (2000). Density values used in other studies (Oppenheimer and Sumner, 1980; Saltus and Jachens, 1995) are similar to those used in this report.

Lithologic logs from thirty-five wells were used to constrain the bedrock depths in the subsurface density model (fig. 12). Of the 35 wells, 21 penetrated bedrock. The remaining logs provide information about the minimum depth to bedrock. The deepest bedrock is $10 \mathrm{~km}$ north of Benson at ADWR well no. 55-568567, a mineral exploration well that penetrated granite at 742-m depth. Bedrock was not penetrated within $512 \mathrm{~m}$ of the land surface at ADWR well no. 55-211774, about $15 \mathrm{~km}$ south of Benson.

\section{Density Model Results}

Major structural features indicated by the density model include a north-south trending gravity low in the southern part of the study area referred to as the Huachuca City subbasin (fig. 12; Gettings and Houser, 2000); a northwest-southeast trending low to the southeast called the Tombstone subbasin; a nearly circular low to the north of Benson in the central part of the study area called the Benson anomaly; and a north-south trending low along the San Pedro River to the north of The Narrows. The Huachuca City and Tombstone subbasins are separated by a gravity high near the San Pedro River (figs. 9, 12). This gravity high continues to the southeast, connecting with exposed bedrock in the Tombstone volcanic field and Mule Mountains near Bisbee. The gravity high and outcrops of Cretaceous crystalline and sedimentary rocks at the center of the Benson subarea about $12 \mathrm{~km}$ south of St. David (Shipman and Ferguson, 2006) indicate that a buried fault-block bisects the Benson subarea in a southeast-northwest direction.

The basin gravity anomaly in the Benson area reflects the complicated geology at the southeast corner of the Catalina core complex (figs. 9, 12). The circular Benson subbasin is only about $15 \mathrm{~km}$ across, while the east-west extent of surficial alluvium is about $30 \mathrm{~km}$, from the Martinez Ranch Fault in the west to the Little Dragoon Mountains in the east (fig. 12). The Martinez Ranch Fault juxtaposes Lower Cretaceous Bisbee Group on the west against mostly basin fill deposits to the east (Dickinson, 1991). The lack of a prominent gravity anomaly to the east of this fault indicates either a thin sequence of basin fill 
or a thick sequence of higher density Pantano Formation, or a combination of both. The Pantano Formation is exposed outside of the study area about $15 \mathrm{~km}$ east of Benson and underlies the lower basin fill in much of the Sierra Vista subwatershed (Brown and others, 1966; Pool and Coes, 1999), suggesting that the Pantano Formation may underlie the lower basin fill in the middle San Pedro watershed. The Benson fault to the southwest of the Benson anomaly, on the northern end of the Whetstone Mountains, does not appear to be a basin-bounding fault. The gravity high in this area may be indicative of buried intrusive rocks (Gettings, 1996). In contrast, the east side of the Whetstone Mountains and the southwest side of the Dragoon Mountains display steep horizontal gravity gradients, indicative of basin-bounding faults. The presumed fault bounding the west side of the Tombstone subbasin, if traced further north, coincides neatly with the west edge of the Benson subbasin.

Lack of knowledge of the presence or absence of midTertiary Pantano Formation in the study area is the biggest obstacle to accurately calculating basin depths. A well log from the Century Petroleum-Colglazier \#1 oil exploration well, about $12 \mathrm{~km}$ west of Benson, indicates multiple occurrences of "red beds" at depths of $18 \mathrm{~m}$ to $147 \mathrm{~m}$. Red beds in a deep exploratory well in the Tucson basin have been identified as Pantano Formation (Dickinson, 1991). Many other driller's logs in the Benson and St. David areas also mention red beds, although these probably indicate the prominent red beds of the lower division of the St. David Formation. The density of indurated parts of the Pantano Formation was estimated
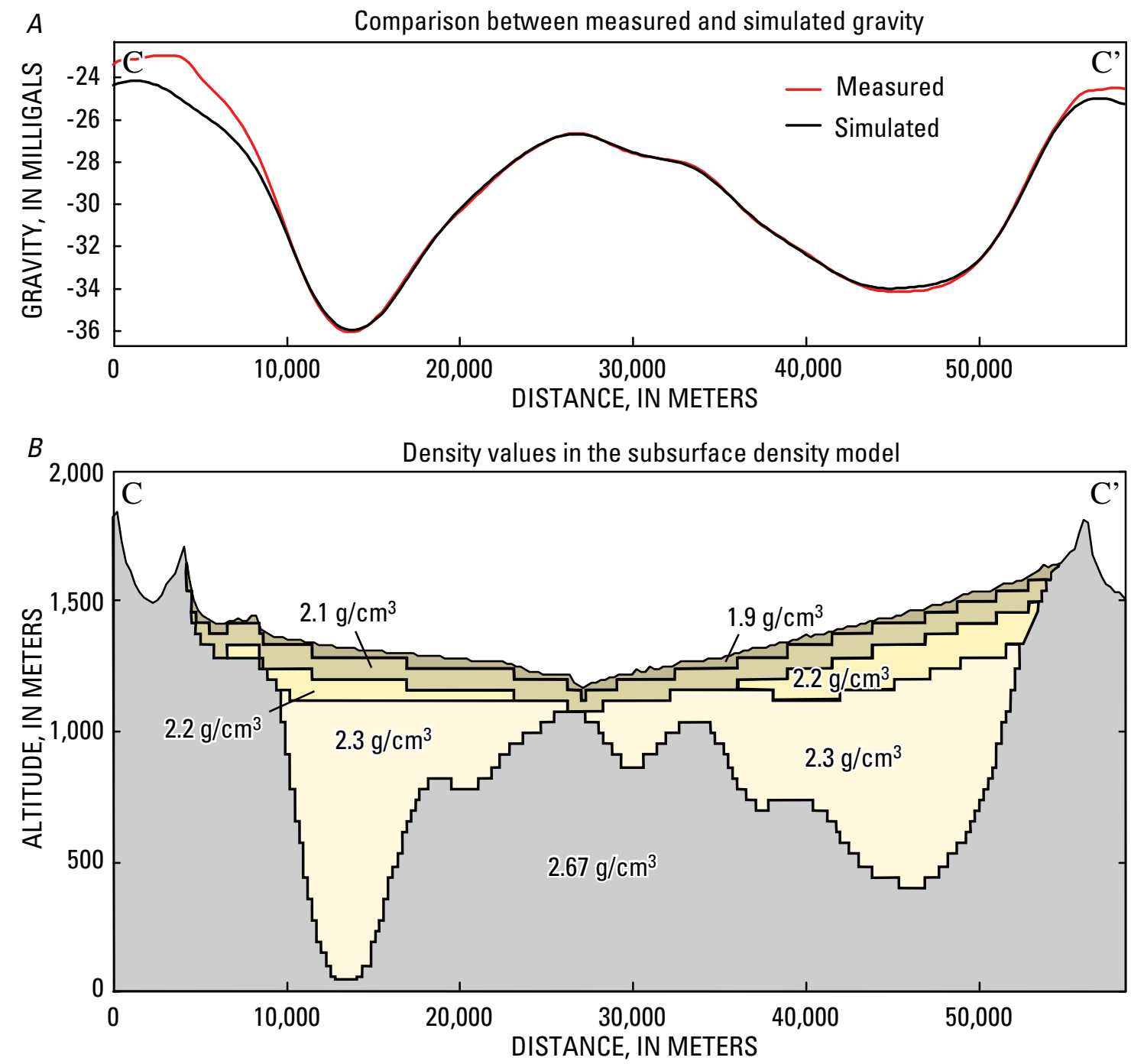

Figure 11. Section $C-C^{\prime}$ (fig. 9) showing the layers in the subsurface density model and gravity values. $A$, Comparison between measured and simulated gravity. $B$, Density values in the subsurface density model. The layers in the model represent bedrock (density of $2.67 \mathrm{~g} / \mathrm{cm}^{3}$ ), lower basin fill (density of $2.3 \mathrm{~g} / \mathrm{cm}^{3}$ ), and upper basin fill (density values from $2.2 \mathrm{~g} / \mathrm{cm}^{3}$ to $1.9 \mathrm{~g} / \mathrm{cm}^{3}$ ). 


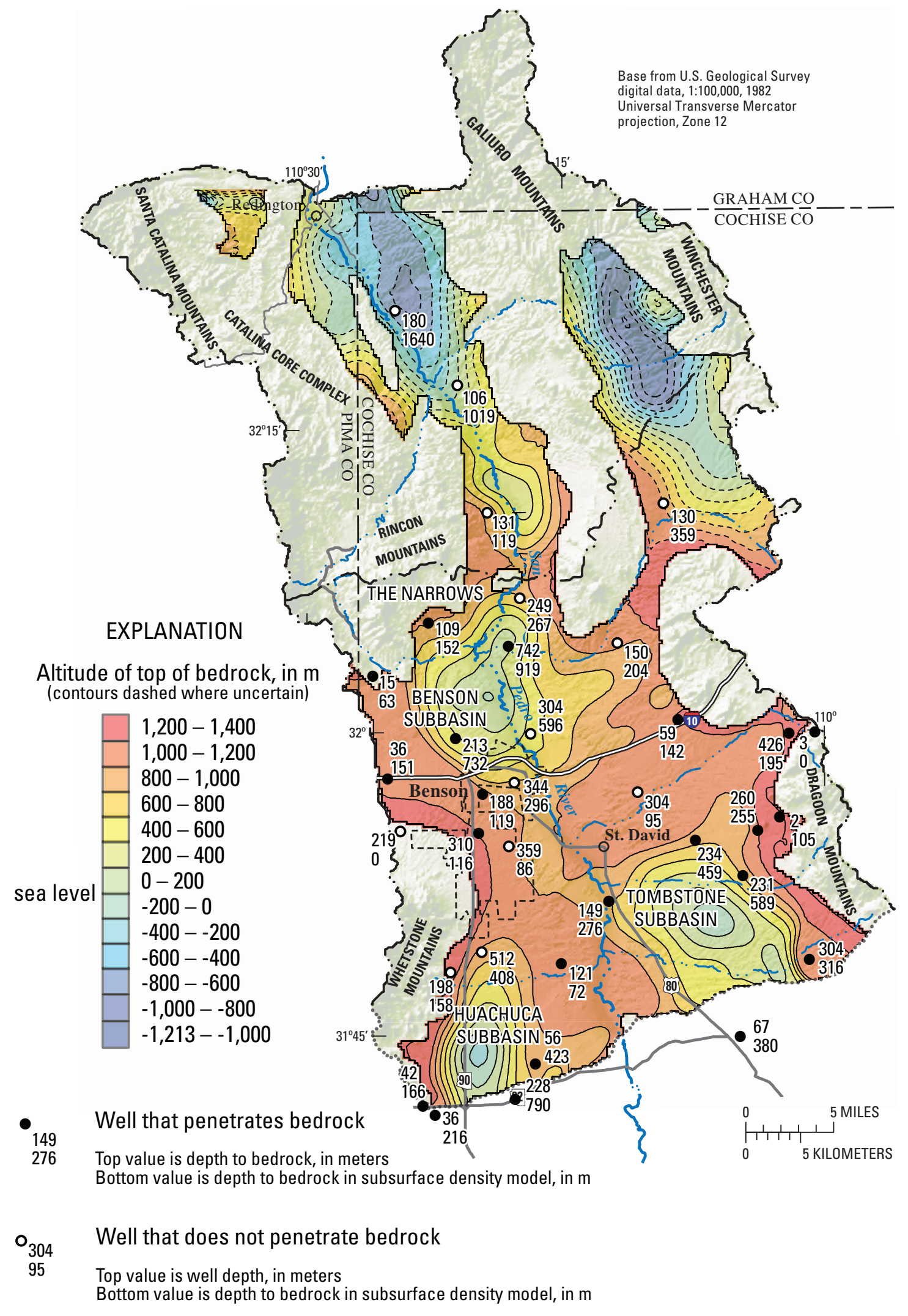

Figure 12. Bedrock altitude determined from subsurface density model in the middle San Pedro watershed, southeastern Arizona. Locations of wells used to constrain the model are shown; these wells provide either an altitude at which bedrock was penetrated or a maximum bedrock altitude if the well did not penetrate bedrock. 
at $2.35 \mathrm{~g} / \mathrm{cm}^{3}$ (Gettings and Houser, 2000), between those of basin fill and basement rock. Although omitted from the subsurface density model, the Pantano Formation, if present in large thicknesses, would cause basin depths to be underestimated by the gravity method.

Bedrock depths are uncertain at a prominent gravity low in the northwestern part of the Narrows-Redington subarea. Interpretation of this gravity low is complicated by insufficient descriptions of subsurface lithology from drill logs and uncertain thickness of late Oligocene volcanic rocks in the Galiuro Mountains, both items of information needed for the subsurface density model. The Oligocene volcanic rocks have a density of about $2.43 \mathrm{~g} / \mathrm{cm}^{3}$ (Schwartz, 1990), between those of the basin fill and crystalline bedrock. Therefore, the source of these gravity lows could be either thick sequences of volcanic rocks, a lesser amount of basin fill, or some combination of volcanics and basin fill. In general, the presence of volcanic rocks having intermediate density (between basin fill alluvium and crystalline bedrock), which are not accounted for in the model, results in underestimates of the depth of the interface between basin fill alluvium and bedrock.

\section{Distribution of Holocene Stream Alluvium}

Targeted surface surveys were done to characterize the geophysical and hydrologic properties of stream alluvium near the San Pedro River. Seismic refraction, magnetic, TEM, and CSAMT surveys by The University of Arizona Department of Mining and Geological Engineering Geophysics Field Methods class were done near The Narrows in the Three Links Farm, near Pomerene, and near St. David. Surveys near The Narrows were done to characterize buried structures in areas of shallow bedrock. Surveys near Pomerene and St. David were done to estimate the thickness and extent of streambed alluvium near the San Pedro River. Results indicated that streambed alluvium thickness varies along the length of the San Pedro River but is generally less than $10 \mathrm{~m}$.

\section{Hydrogeologic Framework Model}

A three-dimensional hydrogeologic framework model (HFM) was constructed to represent the HGUs and major structures in the middle San Pedro watershed. The HFM provides a mechanism to systematically compile and visualize the stratigraphy of the HGUs. The HFM comprises HGUs that are spatially extensive and have similar geologic and waterbearing properties. HGUs in the HFM are the most important units with regard to regional groundwater flow.

\section{Construction of the Hydrogeologic Framework Model}

Methods for the construction of the HFM are based on those used by Faunt and others (2004) and Dickinson and others (2006). The rocks and sediments were divided into four HGUs on the basis of physical characteristics and waterbearing properties. The HFM represents the HGUs by using a vertical sequence of three-dimensional (3D) volumes. Each volume represents the physical spatial extent and thickness of the rocks and sediments contained in each HGU (table 2).

Several software packages were selected for various parts of the HFM construction process. The HFM was

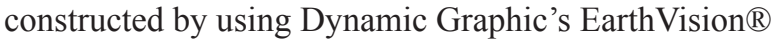

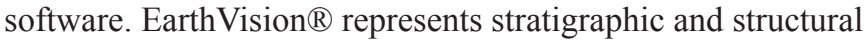
relations of sedimentary basins, including deposition, erosion, and unconformities, as well as truncation of units and faulting. Spatial data, such as digital elevation, outcrop, and borehole information, were compiled and manipulated using Environmental Science Research Institute's (ESRI) ArcGIS $®$ geographic information systems (GIS) software. Modeled bedrock surfaces were exported from Geosoft's Oasis Montaj ${ }^{\circledR}$ software and Golden Software's Surfer ${ }^{\circledR}$ software. Electrical-resistivity models were exported from Petros Eikon's EMIGMA ${ }^{\circledR}$ software.

The HFM is formed by a vertical stack of mostly horizontal 3D grids that represent the spatial extent and thickness of the HGUs. After data were imported from other software packages, grids representing the HGUs were constructed using EarthVision ${ }^{\circledR}$. The grid for each HGU is oriented along principal north-south directions. The datum of the HFM grid is the Universal Transverse Mercator (UTM) projection Zone 12, North American Datum 1983 (NAD 83). The north and south boundaries of all grids are at UTM northing 3,595,000 m and 3,495,000 $\mathrm{m}$, respectively. The west and east boundaries of all grids are at UTM easting 533,000 m and 606,000 m respectively. Grids for each HGU have uniform horizontal discretization in the east-west and north-south directions of $100 \mathrm{~m}$; they are divided into 731 nodes in the east-west direction and 1,001 nodes in the north-south direction. The vertical discretization ranges from $0 \mathrm{~m}$ to the maximum thickness of each HGU (several thousand meters for the bedrock HGU). Software constraints require that the HFM grid be constructed for a bounding rectangle, but the HGU grids are truncated at any lateral or vertical boundary to represent realistic spatial extents that match the extents of units described on geologic maps, well logs, or geophysical models. The altitude of the HFM extends from $500 \mathrm{~m}$ below to 2,500 $\mathrm{m}$ above the vertical datum (altitude of $0 \mathrm{~m}, \mathrm{NGVD} 29$ ) to encompass nearly all of the aquifer units, structural troughs, and mountains in the study area.

\section{Modeled Hydrogeologic Units}

The bedrock HGU represents pre-Tertiary bedrock and pre-basin-and-range sediments that form the mountains and underlie the basin fill units. The bedrock HGU represents rocks that are likely to be poorly water bearing. Exceptions are porous limestone rocks that were not modeled separately from other bedrock because the limestone is difficult to represent structurally by the HFM. The top of the bedrock HGU is 
Table 2. Data sources for hydrogeologic units represented by the hydrogeologic framework model.

[Data sources are used to define the top of a unit, and the bottom of a unit is defined by the top of the underlying unit. The units are listed in stratigraphic stacking order in the hydrogeologic framework model. --, not included]

\begin{tabular}{lccccc}
\hline Hydrogeologic Unit & Topographic data & Borehole lithology & $\begin{array}{c}\text { Borehole } \\
\text { geophysics }\end{array}$ & $\begin{array}{c}\text { Electrical resistivity } \\
\text { models }\end{array}$ & $\begin{array}{c}\text { Subsurface density } \\
\text { models }\end{array}$ \\
\hline $\begin{array}{l}\text { Interbedded lower } \\
\text { basin fill }\end{array}$ & --- & $\mathrm{X}$ & $\mathrm{X}$ & $\mathrm{X}$ & -- \\
$\begin{array}{c}\text { Fine-grained lower } \\
\text { basin fill }\end{array}$ & --- & $\mathrm{X}$ & $\mathrm{X}$ & $\mathrm{X}$ & -- \\
$\begin{array}{c}\text { Coarse-grained lower } \\
\text { basin fill }\end{array}$ & --- & $\mathrm{X}$ & $\mathrm{X}$ & $\mathrm{X}$ & -- \\
Bedrock & $\mathrm{X}$ & $\mathrm{X}$ & $\mathrm{X}$ & --- & $\mathrm{X}$ \\
\hline
\end{tabular}

defined by results from the subsurface density model. Overlying the bedrock is the coarse-grained lower basin fill (CLBF) HGU, which represents the permeable sands and gravels of the lower basin fill that underlie fine-grained basin fill along the central axis of the basin and along the margins. Next is the fine-grained lower basin fill (FLBF) HGU, which represents thick sequences of silt and clay sediments deposited in lacustrine facies exposed along the central axis. Along the flanks and overlying some areas of the FLBF is the interbedded lower basin fill (ILBF) HGU, comprising clay and silt interbeds in sand and gravels, which represents sediments that become more coarse outward from the central axis of the basin to the margins.

\section{Data Inputs}

Data inputs were used to define the vertical sequence, top elevations, and extents of the HGUs. The input data were compiled and selected in order to build an HFM that represents the conceptual model of the hydrogeology developed in this study. Necessary data include land surface elevation, extent of exposed geologic units from maps, stratigraphic relations of HGUs from vertical sections, drill logs containing depths of units below the surface, geophysical models of electrical properties that can be related to lithology, depth to bedrock, and hydrologically important subsurface structures inferred from subsurface density models, electrical-resistivity models, and maps of geologic structures.

Topographic Data.-Digital Elevation Models (DEMs) from the 7.5 minute National Elevation Data (NED) DEMs were used to constrain the top surface of the uppermost HGUs. Data were downloaded from the U.S. Geological Survey Seamless Server (accessed August, 2007) in UTM projection Zone 12, North American Datum 1983 (NAD83). Elevation data were manipulated into $100-\mathrm{m}$ grid resolution. Topographic data were used to assign elevations to the top of driller's logs for wells without elevation data.
Surface Geology.-Data from geologic maps were used to identify the extent of hydrogeologic units on the land surface. In the Benson subarea, the main sources of data were the 1:125,000-scale geologic map of southeastern Arizona by Drewes and others (2002) and the 1:500,000-scale geologic map of Arizona containing many sources and compiled by Hirschberg and Pitts (2000). In the Narrows-Redington subarea, the main sources of data were the 1:125,000-scale map by Dickinson and others (2002) and the 1:24,000-scale map compiled by Bolm and others (2002). The altitudes of geologic units were computed by integrating the geologic map with a DEM. GIS tools were used to create and export $\mathrm{x}, \mathrm{y}, \mathrm{z}$ coordinate locations for outcrops and exposures of each HGU, which constrained HGU positions within the HFM. Table 2 lists geologic units in the geologic reports and maps and the corresponding HGUs contained in the HFM.

Borehole Lithology Data.-Lithology data from 1,350 wells were compiled and manipulated to obtain lithologic contacts between HGUs (fig. 5). Lithology logs of cuttings and core material provided the majority of information to delineate the spatial extents and thicknesses of shallow water-bearing stream alluvium near the San Pedro River and the thicknesses of the fine-grained sections of the lower basin fill at the center of the basin. Data were assembled from the Ground Water Site Inventory databases of the USGS and ADWR and from the ADWR 55 registry database. The lithology logs are widely distributed across the basin, and the densest concentrations of these logs are within several kilometers of the San Pedro River and near Benson, St. David, and Pomerene (fig. 5). Tops and bottoms of vertical lithology intervals were digitized and assigned altitudes on the basis of the elevation of the well at the land surface and depth along the well log. The vertical lithology intervals were assigned to an HGU on the basis of texture and location within the known extent of the HGU.

Borehole Geophysical Data.-Direct-current resistivity logs, sonic velocity, and drill logs are available for two wells, D-17-20 31AAB and D-17-20 33DCC, which are about $2 \mathrm{~km}$ 
apart on the west side of the basin near Benson (fig. 5). The logs were digitized and used to pick top and bottom surfaces of several HGUs on the basis of electrical resistivity and density.

Airborne Transient Electromagnetic Data.-Airborne TEM data were used to identify the extent of silt and clay layers in the basin fill and to infer areas of shallow bedrock. Each modeled TEM section line was exported to EMIGMA $\AA$ as a set of data points with $\mathrm{x}, \mathrm{y}, \mathrm{z}$ coordinates and a value for electrical resistivity. The modeled TEM data were imported into Earthvision ${ }^{\circledR}$ as a three-dimensional dataset. The electrical resistivity values were used to infer the lithology of sediments on the basis of previous descriptions of the geophysical properties of basin fill sediments (table 1). The tops of the fine-grained and medium-grained HGUs were digitized using uppermost altitudes of resistivity-model layers with resistivity values between 0 to $10 \mathrm{ohm}-\mathrm{m}$ and 10 to $20 \mathrm{ohm}-\mathrm{m}$, respectively.

Subsurface Density Models and Structures.-Grids for the tops of modeled bedrock from subsurface density models were used to define the top of relatively impermeable rocks and consolidated sediments. Mapped faults are not defined in the HFM, but are represented by steep vertical gradients in the depth-to-bedrock grids that serve as approximations for vertical offsets in bedrock. The grids were exported from Oasis Montaj ${ }^{\circledR}$ and Surfer ${ }^{\circledR}$ software as $\mathrm{x}, \mathrm{y}, \mathrm{z}$ coordinates and used to define the top of the bedrock HGU. Topographic data for exposed rocks associated with subsurface bedrock were joined with bedrock surface grids in order to create a continuous surface that represents the bottom zone of the HFM.

\section{Gridding of Hydrogeologic-Unit Horizons}

The grids for the top surfaces of the HGUs were computed from data for the top and bottom surfaces of the HGUs (see the "Data Inputs" section). The minimum-tension algorithm available in EarthVision ${ }^{\circledR}$ was used to calculate each grid. The minimum-tension algorithm calculates a smooth surface that closely fits the input data values by using biharmonic-cubic spline interpolation techniques (Dynamic Graphics Inc., 1999). This algorithm produces a trend surface in areas of sparse data that accurately represents the data points. However, in some areas with no data, the algorithms can produce grid elevations that are higher than the land surface, so each grid was constrained by the topographic surface from DEMs.

The accuracy of the grid in representing the top of HGUs depends on the available data and the spatial complexity of the HGU. For example, because of their relatively simple geometry, sedimentary HGUs that were deposited relatively flat with planar beds can be represented more accurately with only a few data points, whereas faulted and folded rocks with more complex geometries are more difficult to represent even with a large number of data points. HGU horizons near the surface, such as the top of fine-grained lower basin fill (FLBF), were relatively well defined by numerous well-distributed data. Lack of data along the basin margins resulted in poorly defined top elevations for the coarse-grained lower basin fill (CLBF) at the margins, but numerous wells penetrate the top of the CLBF underlying the FLBF at the basin center. In areas of sparse data for the CLBF, top elevations were assumed to be similar to top altitudes of the fine-grained lower basin fill unit exposed at the basin center. In general, the stratigraphically lower HGUs are less well defined than more shallow units because data for the lower HGUs are sparse. In areas of sparse data, gridded surfaces were enhanced by using specified "control points" to ensure that the surfaces followed structural trends and honored data.

\section{Building the Model}

The hydrogeologic framework model (HFM) was constructed in the software Earthvision ${ }^{\circledR}$ by stacking the grids that represent the top altitudes of the HGUs into a threedimensional volume (fig. 13). The grids are stacked in an order that produces reasonable approximations for the extents and thicknesses (table 2). The lowest HGU is the bedrock HGU. Above the bedrock is the grid that represents the top of the CLBF. The FLBF overlies the coarse-grained lower basin fill unit, and the grid for the ILBF is overlain on the top of both the FLBF and CLBF. Finally, to ensure that the top of the highest unit conforms to the land surface, a grid based on the land surface DEM truncates the uppermost surface.

\section{Description of the Hydrogeologic Framework Model}

The HGUs as they are depicted in the HFM are described below. The HFM characterizes the extent and saturated thickness of the CLBF (fig. 14), and the extent and thickness of the FLBF (fig. 15) and the ILBF (fig. 16) HGUs.

\section{Bedrock}

The bedrock HGU forms the base of the HFM at an arbitrary depth of $-500 \mathrm{~m}$. The unit represents all pre-Tertiary rocks and sediments predating basin-and-range deformation that form the mountains that bound the basin and underlie the basin fill. The top of the unit conforms to the land surface along mountains and to altitudes estimated from the subsurface density models in the middle San Pedro watershed (fig. 13). In addition, the unit is exposed in areas of bedrock outcrops in the southern portion of the study area and at The Narrows.

\section{Coarse-Grained Lower Basin Fill}

The CLBF generally exists in all areas where bedrock is not exposed at the surface (fig. 14). Most wells in the basin penetrate to the top of the unit, and a large number of lithologic logs were available to define the top surface near Benson, Pomerene, and St. David (fig. 5). The wells range from $100 \mathrm{~m}$ to $350 \mathrm{~m}$ in depth and extend through the fine-grained 
and interbedded facies of the lower basin fill, which can have a combined thickness of as much as $300 \mathrm{~m}$ (figs. 15, 16). The unit is also well defined by geophysical logs for wells D-17-20 17AAB and D-17-20 33DCC near Benson (fig. 6).

The top of the CLBF is highest along the basin margins as defined by the geophysical logs, and lowest where overlain by fine-grained and interbedded lower basin fill facies at the basin center. The top of the unit represents the top of coarser-grained facies, which were lowest in the center of the basin because of increased deposition of fine-grained facies as the lacustrine and playa facies began to dominate in the basin center. The top of the unit slopes gradually down to the north, similar to the present topography, and it slopes most in the center of the basin because the fine and interbedded facies become thicker to the north.

\section{Fine-Grained Lower Basin Fill}

The FLBF follows the central north-south axis of the basin in the Benson subarea (fig. 15). The fine-grained facies exist in the Narrows-Redington subarea but are not included in the HGU there owing to paucity of data. Drill logs in the Narrows-Redington subarea are of insufficient quantity and quality to identify the facies, and the airborne TEM survey did not include all of the subarea. In the Benson subarea, the extent and thickness of the FLBF is defined by many drill logs that penetrate through the unit into the underlying CLBF (figs. 7 and 8, panel $C$ ). In areas without drill logs, the extent of the FLBF was primarily defined by electrically conductive areas having electrical resistivity of less than $10 \mathrm{ohm}-\mathrm{m}$, as determined by interpolated $1 \mathrm{D}$
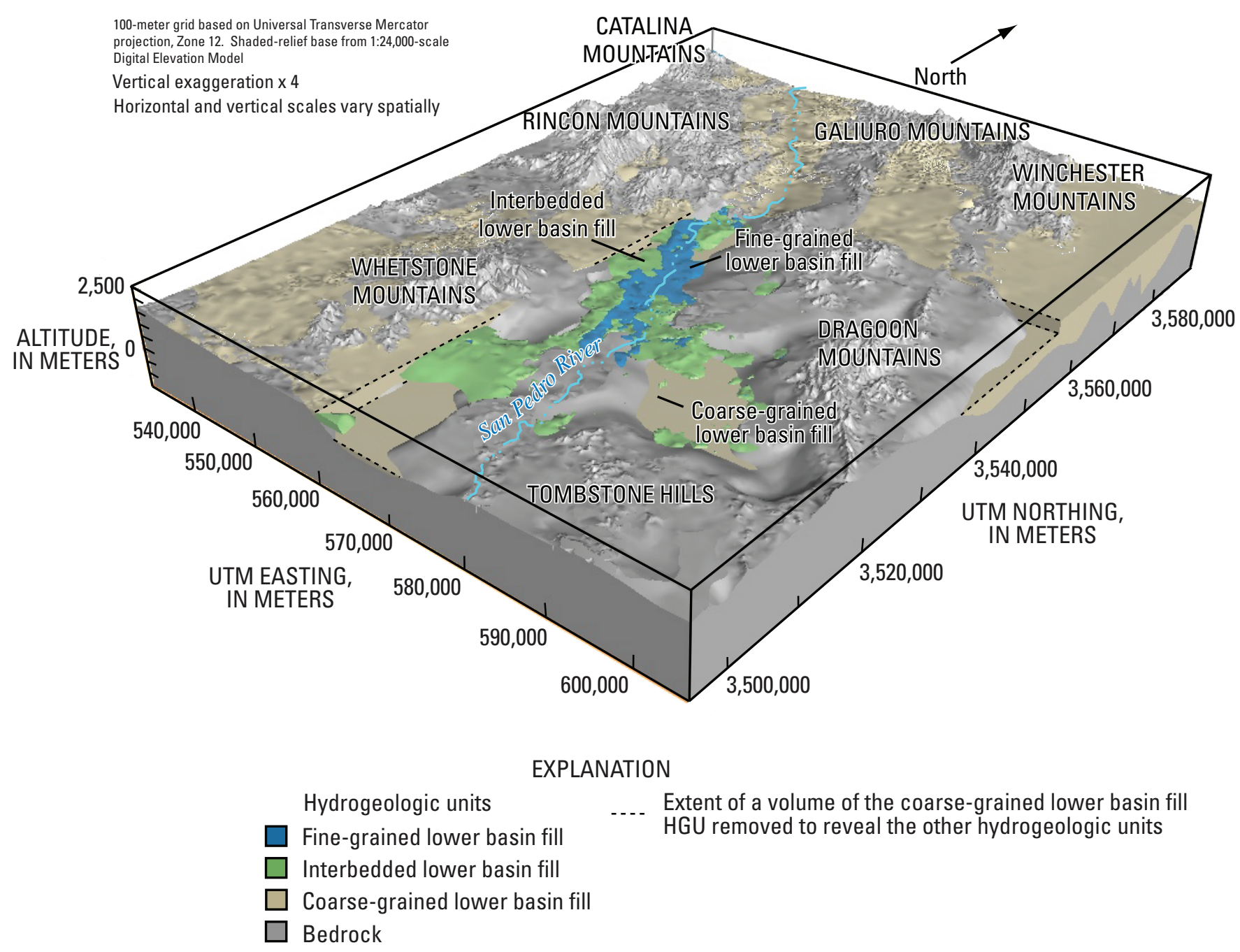

Figure 13. Oblique view of a 3D block diagram of the hydrogeologic framework model of the middle San Pedro watershed, southeastern Arizona. The colors represent 3D volumes of the bedrock and fine, interbedded, and coarse lower basin fill hydrogeologic units. The bedrock and fine and interbedded lower basin fill hydrogeologic units are revealed after removing an arbitrary rectangular volume of the coarse lower basin fill. The dashed lines represent the extent of the removed volume. 
EXPLANATION

Saturated thickness of the coarse-grained lower basin fill $\mathrm{HGU}$ in the HFM, in meters

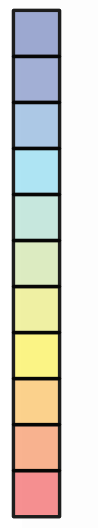

$0-100$

$100-200$

$200-300$

$300-400$

$400-500$

$500-600$

$600-700$

$700-800$

$800-900$

$900-1,000$

greater than 1,000

$\widehat{A}$ A Line of geologic section

Extent of the coarse-grained lower basin fill HGU
Base from U.S. Geological Survey

digital data, 1:100,000, 1982

Universal Transverse Mercator projection, Zone 12 


\section{EXPLANATION}

Thickness of the fine-grained lower basin fill HGU in the HFM, in meters

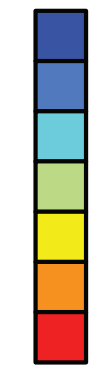

$0-50$

$50-100$

$100-150$

$150-200$

$200-250$

$250-300$

Greater than 300

$\widehat{A} A^{\prime}$

Line of geologic section

Extent of interpolated electrical resistivity values between 0 to $10 \mathrm{ohm}-\mathrm{m}$ within $200 \mathrm{~m}$ of the land surface
Base from U.S. Geological Survey

digital data, 1:100,000, 1982

Universal Transverse Mercator

projection, Zone 12 


\section{EXPLANATION}

\section{Thickness of the interbedded} lower basin fill HGU in the HFM, in meters

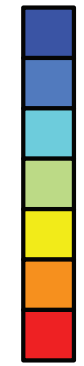

$0-50$

$50-100$

$100-150$

$150-200$

$200-250$

250 - 300

Greater than 300

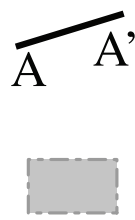

Line of geologic section

Extent of interpolated electrical resistivity values between 10 to $20 \mathrm{ohm}-\mathrm{m}$ within $200 \mathrm{~m}$ of the land surface

Figure 16. Extent and thickness of the interbedded lower basin fill hydrogeologic unit (HGU) represented in the hydrogeologic framework model (HFM) of the middle San Pedro watershed, southeastern Arizona. The extent and thickness were determined from drill logs and one-dimensional models of electrical resistivity. 
electrical-resistivity models. The thickness was defined both by the top and bottom of electrically conductive areas along airborne TEM sections and by lithologic descriptions in drill logs. The thickness increases from south to north. Thin areas are near high bedrock along the southern areas (near airborne TEM section line 38030, fig. 4), and the thickness increases to about $300 \mathrm{~m}$ between Pomerene and The Narrows. The thickest areas correspond to the playa depocenter of the St. David Formation described by Smith (1994). In the Benson subarea, the FLBF underlies much of the San Pedro River, which may result in complicated groundwater/surface water interactions that require investigation with numerical groundwater-flow models.

\section{Interbedded Lower Basin Fill}

The interbedded lower basin fill unit (ILBF) represents interbedded fine-grained sediments within sands and gravels between the fine-grained and coarse-grained lower basin fill units (fig. 16). The interbedded lower basin fill unit is present along the outer margins of the fine-grained lower basin fill unit and commonly at similar altitudes (figs. 7 and 8, panel C). The unit is generally less than $100 \mathrm{~m}$ thick. Near St. David and south toward areas of high bedrock the unit underlies the San Pedro River.

\section{Hydrologic Properties of Hydrogeologic Units}

Knowledge of the hydrologic properties of the HGUs that control the rates and direction of groundwater flow and responses to stresses is necessary to construct accurate and reliable groundwater-flow models. The most important properties for groundwater models are saturated thickness, horizontal and vertical hydraulic conductivity, aquifer thickness, specific yield, and specific storage.

Hydrologic properties of basin fill aquifers in Arizona have been well characterized by previous studies (Anderson and Freethey, 1995). Previous values of the hydrologic properties for the Upper and Lower San Pedro Basins estimated by aquifer tests and specific capacity are summarized here to describe the ranges of hydrologic properties of the HGUs.

\section{Aquifer-Test Data}

Published aquifer-test data are available for wells operated by the city of Benson, in planned areas of future development east of the Whetstone Mountains, and near the Apache Nitrogen Superfund Site (Hargis + Associates Inc., 2008). Transmissivity estimates for four wells that penetrate the coarse facies of the lower basin fill range from 24 to 1,600 $\mathrm{m}^{2} / \mathrm{d}$ (Daniel Weber, Errol L. Montgomery \& Associates, written commun., 2009). Storativity (the product of specific storage and aquifer thickness) and specific yield values for the four wells range from 0.0003 to 0.0007 and from 0.001 to 0.02 , respectively. Values of transmissivity, $T$, can be converted to hydraulic conductivity, $K$, using the relation
$K=T / b$, where $b$ is the assumed aquifer thickness. In cases where the perforated interval of a well penetrates the full saturated thickness of an aquifer and flow is generally horizontal near the well, the length of the perforated interval can approximate the thickness $b$. The approximated horizontal hydraulic conductivity values of the wells in the coarse-grained facies of the lower basin fill range from 0.14 to $13 \mathrm{~m} / \mathrm{d}$, and the ratios between horizontal and vertical hydraulic conductivity range from 70:1 to 15:1. The aquifer test in the stream alluvium near the Apache Nitrogen Superfund Site indicated a horizontal hydraulic conductivity of $90 \mathrm{~m} / \mathrm{d}$ and specific yield in the range of 0.03 to 0.05 .

\section{Specific-Capacity Data}

In the absence of aquifer test data, potential groundwater declines owing to pumping can be inferred by well productivity. Well productivity can be expressed in terms of the specific capacity $C_{\mathrm{s}}$, as $C_{\mathrm{s}}=Q / \Delta h_{w}$, where $Q$ is the pumping rate and $\Delta h_{w}$ is the drawdown in the well. The specific capacity is dependent on well construction and efficiency and only reflects aquifer properties near the well. Specific capacity values (table 3 ) are primarily available for the coarsegrained facies of the lower basin fill and have a maximum of $1,640 \mathrm{~m}^{3} / \mathrm{d} / \mathrm{m}$ at a well in the Narrows-Redington subarea. The specific capacity values are consistent with the expected hydraulic properties of the coarse-grained facies of the lower basin fill.

\section{Saturated Thickness of Coarse-Grained Lower Basin Fill}

The saturated thickness of the coarse-grained lower basin fill (CLBF) largely governs the amount of groundwater flow in the regional aquifer (fig. 14). The saturated thickness varies from about $1,000 \mathrm{~m}$ to near zero as the unit thins along mountain fronts. In unconfined areas, the saturated thickness was determined by subtracting the water table elevation from the bottom of the CLBF determined from drill logs and the subsurface density model. In confined areas, the saturated thickness was calculated by subtracting the bottom of the confining FLBF from the bottom of the CLBF. The water table elevation was estimated by interpolation of water-level data measured by ADWR (Arizona Department of Water Resources, 2009) during October-November 2006. The bottom elevation and extent of the FLBF was determined from calculations by the hydrogeologic framework model using drill log data. The extent of the FLBF was determined by the extent of the areas with electrical resistivity less than $20 \mathrm{ohm}-\mathrm{m}$ simulated by the $1 \mathrm{D}$ electrical-resistivity models. The greatest saturated thickness of the CLBF is in subbasin areas estimated by the subsurface density models. The thickest area is in the NarrowsRedington subarea south of Redington. Other thick areas are in the Benson subbasin, southeast of St. David in the Tombstone subbasin, and in the Huachuca City subbasin (fig. 14). The saturated thickness thins to less than $400 \mathrm{~m}$ in confined areas underlying the FLBF in areas of high bedrock near St. David. 
Table 3. Available specific capacity data for wells in the middle San Pedro watershed, southeastern Arizona.

[CLBF, coarse-grained lower basin fill; SA, stream alluvium]

\begin{tabular}{|c|c|c|c|c|c|c|c|}
\hline Local well name & $\begin{array}{l}\text { Well depth, } \\
\text { meters }\end{array}$ & $\begin{array}{c}\text { Principal } \\
\text { hydrogeologic } \\
\text { unit }\end{array}$ & $\begin{array}{l}\text { Discharge } \\
\text { rate }\left(\mathrm{m}^{3} / \mathrm{min}\right)\end{array}$ & $\begin{array}{c}\text { Static depth } \\
\text { to } \\
\text { water, } m\end{array}$ & $\begin{array}{c}\text { Production } \\
\text { depth to } \\
\text { water, } m\end{array}$ & $\begin{array}{l}\text { Specific } \\
\text { capacity } \\
\left(\mathbf{m}^{3} / \mathrm{d} / \mathrm{m}\right)\end{array}$ & Data source \\
\hline D-12-18 13DBC & 45.7 & CLBF & 2.4 & 18.6 & 20.7 & 1,600 & ADWR \\
\hline D-18-21 16BCD2 & 25.0 & SA & 1.9 & 16.3 & 36.1 & 140 & ADWR \\
\hline D-18-21 16BDB5 & 167.6 & CLBF & 0.2 & 1.5 & 11.2 & 30 & ADWR \\
\hline D-18-21 06ADA3 & 30.2 & SA & 1.9 & 10.7 & 19.8 & 300 & ADWR \\
\hline D-17-21 33CBC & 161.5 & CLBF & 1.6 & 9.9 & 23.3 & 170 & ADWR \\
\hline D-17-21 33CBC & 161.5 & CLBF & 1.6 & 9.9 & 23.3 & 170 & ADWR \\
\hline D-17-21 33CBC & 161.5 & CLBF & 1.6 & 9.9 & 23.3 & 170 & ADWR \\
\hline D-17-21 33CBC & 161.5 & CLBF & 1.6 & 9.9 & 23.3 & 170 & ADWR \\
\hline D-17-21 33CBC & 161.5 & CLBF & 1.6 & 9.9 & 23.3 & 170 & ADWR \\
\hline D-17-21 33CCB2 & 111.6 & CLBF & 1.0 & 6.3 & 58.7 & 30 & ADWR \\
\hline D-17-21 32ADA & 176.8 & CLBF & 1.9 & 21.5 & 47.2 & 110 & ADWR \\
\hline D-17-21 32ADA & 176.8 & CLBF & 1.9 & 21.5 & 47.2 & 110 & ADWR \\
\hline D-17-20 22BDA & 286.5 & CLBF & 1.0 & 23.5 & 68.9 & 32 & ADWR \\
\hline D-17-20 22BDA & 286.5 & CLBF & 1.0 & 23.5 & 68.9 & 32 & ADWR \\
\hline D-17-20 19BBB & 304.8 & CLBF & 1.8 & 177.0 & 180.1 & 840 & ADWR \\
\hline D-17-20 17CCC & 310.9 & CLBF & 1.8 & 142.3 & 152.7 & 250 & ADWR \\
\hline D-17-20 17CCC & 310.9 & CLBF & 1.8 & 142.3 & 152.7 & 250 & ADWR \\
\hline D-17-20 18BBB & 305.7 & CLBF & 0.7 & 142.5 & 145.6 & 300 & ADWR \\
\hline D-17-20 09ADC & 304.8 & CLBF & 1.0 & 7.5 & 65.0 & 25 & ADWR \\
\hline D-17-20 09ADC & 304.8 & CLBF & 1.0 & 7.5 & 65.0 & 25 & ADWR \\
\hline D-16-19 36DBD & 305.7 & CLBF & 1.1 & 64.1 & 67.5 & 470 & ADWR \\
\hline D-16-19 36CAD & 277.4 & CLBF & 1.1 & 66.1 & 69.9 & 420 & ADWR \\
\hline D-16-20 34DBD & 203.0 & CLBF & 0.3 & 16.1 & 38.2 & 20 & ADWR \\
\hline D-16-20 34ACB & 47.5 & CLBF & 1.9 & 23.8 & 32.3 & 320 & ADWR \\
\hline D-16-20 34ACA1 & 35.7 & $\mathrm{SA}$ & 1.1 & 20.7 & 29.3 & 180 & ADWR \\
\hline D-16-19 36CAD & 277.4 & CLBF & 1.1 & 66.0 & 71.0 & 320 & $\begin{array}{c}\text { Montgomery } \\
\text { and } \\
\text { Associates }\end{array}$ \\
\hline D-17-20 17CCC & 310.9 & CLBF & 1.8 & 141.5 & 152.5 & 240 & $\begin{array}{c}\text { Montgomery } \\
\text { and } \\
\text { Associates }\end{array}$ \\
\hline D-17-20 19BBB & 304.8 & CLBF & 1.7 & 176.8 & 180.2 & 720 & $\begin{array}{c}\text { Montgomery } \\
\text { and } \\
\text { Associates }\end{array}$ \\
\hline D-17-20 31BAA & 402.3 & CLBF & 0.2 & 69.6 & 85.2 & 20 & $\begin{array}{c}\text { Montgomery } \\
\text { and } \\
\text { Associates }\end{array}$ \\
\hline
\end{tabular}




\section{Incorporating the Hydrogeologic Framework Model into a Groundwater-Flow Model}

The spatial relations between the HGUs in the HFM describe hydrogeologic zones that define the spatial extent of permeable and impermeable zones. This information is needed by groundwater-flow models such as MODFLOW (Harbaugh, 2005) that use a finite-difference scheme to approximate governing equations within a discretized flow domain. Vertical discretization is commonly referred to as the layers of the model, which are often related to horizontal stratigraphic layers. The model can incorporate hydrogeologic zones within a single or multiple model layers, and a hydrogeologic zone can cover portions of a layer to account for horizontal variations in permeability within that layer.

Hydrogeologic zones created from the lithologic zones (figs. 7 and 8, panel $D$ ) are indicated as model layers that overlap the lithologic zones (figs. 7 and 8, panels $B$ and $C$ ). This configuration includes generally horizontal layers that comprise coarse sediments near the basin margin and fine sediments at the basin center. Layer 6 represents pre-Tertiary granite, limestone, sandstone, siltstone, and mudstone and sediments predating basin-and-range deformation along the margin of the basin fill. Layer 6 is generally impermeable except for local instances of limestone and other permeable sedimentary rocks. Layers 3, 4, and 5 represent saturated lower basin fill sediments, in which layer 5 represents highly permeable sand and gravel that overlie bedrock and underlie clay and silt. Layer 2 represents saturated portions of upper basin fill along the basin margins. Layer 1 represents saturated fine and coarse sediments within the streambed of the San Pedro River, which have been described by previous studies (for example, Pool and Coes, 1999).

Inferred lithologies allow for delineation of permeable and impermeable zones within layers 3,4 , and 5 , which can be used to simulate important features of the groundwaterflow system. Such features include confined groundwater conditions within portions of layers 4 and 5 that underlie the fine-grained hydrogeologic zones within layers 3 and 4 . Additionally, impermeable fine-grained sediments west of the San Pedro River may restrict horizontal groundwater flow from areas of high hydraulic head at the west to areas of lower head near the San Pedro River.

\section{Summary}

This report documents the results of the investigation of the hydrogeologic framework of the middle San Pedro watershed in southeastern Arizona. The overall investigation includes three planned work elements:

1. Refine the hydrogeologic framework;

2. Characterize the groundwater and surface-water system, recharge and discharge processes, and water quality in selected areas; and
3. Develop a predictive numerical groundwater-flow model for examining the potential groundwater and surface-water responses to changes in recharge and discharge.

This report describes existing data, the development of a hydrogeologic conceptual model, extensive geophysical surveys to delineate sediment textures and lithology of the basin fill and to quantify the thickness of basin fill deposits in order to describe hydrologic properties of the aquifer system, and a data management system to incorporate these data into groundwater models. The next two reports would describe the results of work elements 2 and 3.

A hydrogeologic framework model (HFM) was constructed for the purpose of delineating the physical extent and thickness of hydrogeologic units (HGUs) that fit within a three-dimensional volume. The stacking order of the HGUs from the model bottom to the land surface are bedrock, coarsegrained lower basin fill, fine-grained lower basin fill, and interbedded lower basin fill. The bedrock HGU represents preTertiary crystalline and sedimentary rocks and mid-Tertiary sediments predating the basin fill and having low permeability. The top of the bedrock HGU is defined by drill logs that penetrate bedrock and by the top of dense bedrock determined by subsurface density models. The coarse-grained lower basin fill unit represents gravel and sand facies of the lower basin fill at the basin margins and at the center of the basin under finegrained facies. The fine-grained lower basin fill unit represents clay and silt sequences as much as $300 \mathrm{~m}$ thick at the center of the basin that are commonly exposed at the center of the basin. The interbedded lower basin fill unit represents interbeds of clay and silt within sand and gravel along the margins of the fine-grained facies.

HGU spatial extents and thickness simulated by the HFM can be incorporated into groundwater-flow models to define hydrogeologic zones and layers. The saturated thickness of the coarse-grained lower basin fill varies in relation to the depth to underlying impermeable bedrock and the thickness of overlying silt and clay. Three areas where the thickness is about $1,000 \mathrm{~m}$ are south of Redington, northwest of Benson, and southeast of St. David. The thickness is about $600 \mathrm{~m}$ at the southern portion of the study area near the Whetstone Mountains. Thin areas are largely controlled by shallow bedrock that underlies much of the San Pedro River south of Benson and at The Narrows. The extent of the fine-grained lower basin fill is limited to the central north-south axis of the Benson subarea, and the thickness increases northward to about $300 \mathrm{~m}$ south of The Narrows. The interbedded lower basin fill unit is as much as $100 \mathrm{~m}$ thick and is a transition between the coarse-grained and fine-grained lower basin fill units along the margin of the fine-grained facies.

One-dimensional electrical models of airborne TEM surveys were used to map important lithologic and hydraulic property distributions where drill log data are scarce or of uncertain quality. Electrical and geologic properties from two geophysical well logs were closely related to the $1 \mathrm{D}$ resistivity 
distributions and were the basis for defining electrical resistivity values of lithology throughout the alluvial basin. The two geophysical logs and 1D resistivity models identified an upper sequence of highly variable resistivity values identified as interbedded sand, gravel, and clay. Below the upper sequence, the resistivity logs and 1D models range between 5 and $20 \mathrm{ohm}-\mathrm{m}$ within a silt and clay sequence. Underlying the silt and clay to the bottom of the boreholes, the resistivity logs and 1D models increase to several hundred ohm-m and are highly variable within sand and gravel layers. These sequences matched distinct resistivity and lithologic layers identified by geophysical logs in the adjacent Sierra Vista subwatershed, suggesting that these sequences are laterally continuous within both the Benson and Sierra Vista subwatersheds in the Upper San Pedro Basin.

Significant electrical resistivity zones mapped from 1D models of airborne TEM surveys correspond with hydrologically significant lithologic zones (Dickinson and others, in press). Within basin fill sediments, this includes fine-grained zones of silt and clay of poor permeability, medium-grained zones of sand, silt, gravel, and clay, and coarse-grained zones of sand, gravel, and conglomerate. Lithologic zones of crystalline and limestone bedrock underlie the basin fill sediments. New data on spatial extents and thicknesses of the lithologic zones reduces the uncertainty of the extents of high- and low-permeability zones. Improved definition of the hydrologic zones allows for use of a groundwater model to examine other uncertainties.

A subsurface density model was constructed to identify the top of bedrock and structures that may affect regional groundwater flow. Major features include exposed bedrock at The Narrows, a north-south trending gravity low in the southern part of the study area referred to as the Huachuca City subbasin, a northwest-southeast trending low to the southeast called the Tombstone subbasin, a nearly circular low to the north of Benson in the central part of the study area, and a north-south trending low along the San Pedro River to the north. The Huachuca City and Tombstone subbasins to the south are located at the east and west margins of the San Pedro Basin, separated by a gravity high along the present-day San Pedro River. This gravity high continues to the southeast and connects with exposed bedrock in the Tombstone volcanic field and Mule Mountains near Bisbee.

\section{References Cited}

Anderson, T.W., and Freethey, G.W., 1995, Simulation of ground-water flow in alluvial basins in south-central Arizona and parts of adjacent states: U.S. Geological Survey Professional Paper 1406-D, 78 p.

Anderson, T.W., Freethey, G.W., and Tucci, P., 1992, Geohydrology and water resources of alluvial basins in southcentral Arizona and parts of adjacent states: U.S. Geological Survey Professional Paper 1406-B, 67 p.
Annan, A.P., and Lockwood, R., 1991, An application of airborne GEOTEM* in Australian conditions: Exploration Geophysics, v. 22, no. 1, p. 5-12.

Arizona Department of Water Resources, 2005, Groundwater resources of the Upper San Pedro Basin, Arizona: Arizona Department of Water Resources Technical report to the Upper San Pedro Basin AMA review report, 85 p.

Arizona Department of Water Resources, 2009, Groundwater site inventory database: Arizona Department of Water Resources (also available at http://gisweb.azwater.gov/ waterresourcedata/).

Balcer, R.A., 1984, Stratigraphy and depositional history of the Pantano Formation (Oligocene-early Miocene), Pima County, Arizona: Tucson, Arizona, University of Arizona, unpublished M.S. thesis, $107 \mathrm{p}$.

Bankey, V., and Kleinkopf, M.D., 1982, Principal facts for gravity stations in the Whetstone Roadless Area, Arizona: U.S. Geological Survey Open-File Report 82-738, 14 p.

Bills, D.J., Flynn, M.E., and Monroe, S.A., 2007, Hydrogeology of the Coconino Plateau and adjacent areas, Coconino and Yavapai Counties, Arizona: U.S. Geological Survey Scientific Investigations Report 2005-5222, 101 p.

Blasch, K.W., Hoffmann, J.P., Graser, L.F., Bryson, J.R., and Flint, A.L., 2006, Hydrogeology of the upper and middle Verde River watersheds, central Arizona: U.S. Geological Survey Scientific Investigations Report 2005-5198, 115 p.

Bolm, K.S., Lewis, T., Hirschberg, D.M., Pitts, G.S., and Dickinson, W.R., 2002, Spatial digital database for the geology of the San Pedro River Basin in Cochise, Gila, Graham, Pima, and Pinal Counties, Arizona: U.S. Geological Survey Open-File Report 02-393, digital database, version 1.0, http://geopubs.wr.usgs.gov/open-file/of02-393/.

Brocher, T.M., 2005, Empirical relations between elastic wavespeeds and density in the earth's crust: Bulletin of the Seismological Society of America, v. 95, no. 6, p. 2081-2092.

Brown, S.G., Davidson, E.S., Kister, L.R., and Thomsen, B.W., 1966, Water resources of Fort Huachuca Military Reservation, southeastern Arizona: U.S. Geological Survey Water Supply Paper 1819-D, 57 p.

Clay, D.W., 1970, Stratigraphy and petrology of the Mineta Formation, Pima and Cochise Counties, Arizona: Tucson, Arizona, University of Arizona, Ph.D. dissertation, 183 p. 
Coes, A.L., and Pool, D.R., 2007, Ephemeral-stream channel and basin-floor infiltration and recharge in the Sierra Vista subwatershed of the Upper San Pedro Basin, southeastern Arizona, in Stonestrom, D.A., Constantz, J., Ferre, T.P.A., and Leake, S.A., eds., Ground-water recharge in the arid and semiarid southwestern United States: U.S. Geological Survey Professional Paper 1703-J, p. 253-311.

Coes, A.L., Gellenbeck, D.J., and Towne, D.C., 1999, Groundwater quality in the Sierra Vista subbasin, Arizona, 1996-97: U.S. Geological Survey Water-Resources Investigations Report 99-4056, 50 p.

Cooke, R.U., and Reeves, R.W., 1976, Arroyos and environmental change in the American South-West: Oxford, Clarendon Press, 213 p.

Corell, S.W., Corkhill, F., Lovvik, D., and Putnam, F., 1996, A groundwater flow model of the Sierra Vista Subwatershed of the Upper San Pedro Basin-southeastern Arizona: Arizona Department of Water Resources Model Report 10, $107 \mathrm{p}$.

Dater, D., Metzger, D., and Hittelman, A., 1999, Land and marine gravity CD-ROMs: Gravity 1999 edition on 2 CD-ROMs, National Geophysical Data Center, Boulder, Colorado (also available at http://www.ngdc.noaa.gov/mgg/ gravity/1999cd.html).

Dickinson, J.E., Land, M., Faunt, C.C., Leake, S.A., Reichard, E.G., Fleming, J.B., and Pool, D.R., 2006, Hydrogeologic framework refinement, ground-water flow and storage, water-chemistry analyses, and water-budget components of the Yuma area, southwestern Arizona and southeastern California: U.S. Geological Survey Scientific Investigations Report 2006-5135, 88 p.

Dickinson, J.E., Pool, D.R., Groom, R.W., and Davis, L.J., in press, Inference of lithologic distributions in an alluvial aquifer using airborne transient electromagnetic surveys: Geophysics.

Dickinson, W.R., 1991, Tectonic setting of faulted Tertiary strata associated with the Catalina core complex in southern Arizona: Geological Society of America Special Paper 264, $106 \mathrm{p}$.

Dickinson, W.R., 2002, Spatial digital database of the geologic map of Catalina Core Complex and San Pedro Trough, Pima, Pinal, Gila, Graham, and Cochise counties, Arizona [digital database by Hirschberg, D.M., Pitts, G.S., and Bolm, K.S.]: U.S. Geological Survey Open-File Report 2002-365, 25 p.
Dickinson, W.R., 2003, Depositional facies of the Quibruis Formation, basin fill of the San Pedro trough, southeastern Arizona Basin and Range Province, in Raynolds, R.G., and Flores, R.M., eds., Cenozoic Systems of the Rocky Mountain Region: Denver, Colorado, Society for Sedimentary Geology, p. 157-181.

Drewes, H., 2002, Spatial digital database for the tectonic map of Southeast Arizona [digital database by Fields, R.A., Hirschberg, D.M., and Bolm, K.S.]: U.S. Geological Survey Geologic Investigations Series I-1109, 38 p.

Drewes, H.D., 1981, Tectonics of southeastern Arizona: U.S. Geological Survey Professional Paper 1144, 96 p.

Dynamic Graphics Inc., 1999, Getting started with Earthvision 5: Alameda, California, Dynamic Graphics, Inc., 130 p.

Eberly, L.D., and Stanley, T.B., 1978, Cenozoic stratigraphy and geologic history of southwestern Arizona: Geological Society of America Bulletin, v. 89, no. 6, p. 921-940.

Faunt, C.C., Sweetkind, D.S., and Belcher, W.R., 2004, Threedimensional hydrogeologic framework model, in Belcher, W.R., ed., Chapter E of Death Valley regional ground-water flow system, Nevada and California-hydrogeologic framework and transient ground-water flow model: U.S. Geological Survey Scientific Investigations Report 2004-5205, 89 p.

Fenneman, N.M., 1931, Physiography of western United States (1st ed.): New York, McGraw-Hill, 534 p.

Finnell, T.L., 1970, Pantano Formation, in Cohee, G.V., Bates, R.G., and Wright, W.B., eds., Changes in stratigraphic nomenclature by the U.S. Geological Survey, 1968, p. 35-36.

Fleming, J.B., Pool, D.R., and Leenhouts, J.M., 2002, Electrical surveys to define distributions of silt and clay layers near the San Pedro River, Sierra Vista subwatershed of the Upper San Pedro River Basin, in Symposium on the Application of Geophysics to Environmental and Engineering Problems 15, Las Vegas, Nevada, February 2002, Proceedings: The Environmental and Engineering Geophysical Society, p. 1-12.

Freethey, G.W., 1982, Hydrologic analysis of the Upper San Pedro Basin from the Mexico-United States international boundary to Fairbank, Arizona: U.S. Geological Survey Open-File Report 82-752, 64 p.

Gettings, M.E., 1996, Aeromagnetic, radiometric, and gravity data for Coronado National Forest, in du Bray, E.A., ed., Mineral resource potential and geology of Coronado National Forest, Southeastern Arizona and Southwestern New Mexico: U.S. Geological Survey Bulletin 2083-D, p. $70-101$. 
Gettings, M.E., and Houser, B.B., 2000, Depth to bedrock in the upper San Pedro Valley, Cochise County, southeastern Arizona: U.S. Geological Survey Open-File Report 2000138, http://pubs.usgs.gov/of/2000/of00-138/.

Goode, T.C., and Maddock, T.I., 2000, Simulation of groundwater conditions in the Upper San Pedro Basin for the evaluation of alternative futures: The University of Arizona HWR No. 00-030, 113 p.

Gray, R.S., 1967, Petrography of the Upper Cenezoic nonmarine sediments in the San Pedro Valley, Arizona: Journal of Sedimentary Petrology, v. 37, no. 3, p. 774-3790.

Grover, J.A., 1984, Petrology, depositional environments and structural development of the Mineta Formation, Teran Basin, Cochise County, Arizona: Sedimentary Geology, v. 38 , no. 1-4, p. 87-105.

Halvorson, P.H.F., 1984, An exploration gravity survey in the San Pedro Valley, southeastern Arizona: Tucson, Arizona, The University of Arizona, M.S. thesis, $70 \mathrm{p}$.

Harbaugh, A.W., 2005, MODFLOW-2005; the U.S. Geological Survey modular ground-water model - the groundwater flow process: U.S. Geological Survey Techniques and Methods 6-A16, $253 \mathrm{p}$.

Hargis + Associates Inc., 2008, Northern area performance assessment model, Apache Powder Superfund Site, Cochise County, Arizona: prepared for Apache Powder Superfund Site, Cochise County, Arizona, 28 p.

Haynes, C.V., 1981, Geochronology and paleoenvironments of the Murray Springs Clovis site, Arizona: National Geographic Society Research Reports, v. 13, p. 243-251.

Haynes, C.V., 1987, Curry Draw, Cochise County, Arizona; a late Quaternary stratigraphic record of Pleistocene extinction and paleo-Indian activities, in Davis, G.H., and VandenHolder, E.M., eds., Geologic diversity of Arizona and its margins; excursions to choice areas: Tucson, Arizona Bureau of Geology and Mineral Technology Special Paper 5 , p. 23-28.

Hereford, R., 1993, Entrenchment and widening of the Upper San Pedro River, Arizona: Geological Society of America Special Paper 282, 46 p.

Hirschberg, D.M., and Pitts, G.S., 2000, Digital geologic map of Arizona; a digital database derived from the 1983 printing of the Wilson, Moore, and Cooper 1:500,000-scale map: U.S. Geological Survey Open-File Report 2000-409, $67 \mathrm{p}$.

Jahnke, P., 1994, Modeling of groundwater flow and surface/ groundwater interaction for the San Pedro River Basin from Fairbank to Redington, Arizona: Tucson, The University of Arizona, M.S. thesis.
Kane, M.F., 1962, A Comprehensive system of terrain corrections using a digital computer: Geophysics, v. 27, no. 4, p. 445-3462.

Ladd, T.W., 1975, Stratigraphy and petrology of the Quiburis Formation near Mammoth, Pinal County, Arizona: Tucson, Arizona, The University of Arizona, M.S. thesis, 102 p.

LaFehr, T.R., 1991, An exact solution for the gravity curvature (Bullard B) correction: Geophysics, v. 56, no. 8, p. 1179-1184.

Leenhouts, J.M., Stromberg, J.C., and Scott, R.L., 2006, Hydrologic requirements of and consumptive ground-water use by riparian vegetation along the San Pedro River, Arizona: U.S. Geological Survey Scientific Investigations Report 2005-5163, 154 p.

Melton, M.A., 1965, The geomorphic and paleoclimatic significance of alluvial deposits in southern Arizona: The Journal of Geology, v. 73, no. 1, p. 1-38.

Menges, C.M., and Pearthree, P.A., 1989, Late Cenozoic tectonism in Arizona and its impact on regional landscape evolution, in Jenny, J.P., and Reynolds, S.J., eds., Geologic evolution of Arizona: Tucson, Arizona, Arizona Geological Society, p. 649-680.

Morrison, R.B., 1985, Pliocene/Quaternary geology, geomorphology, and tectonics of Arizona: Geological Society of America Special Paper 203, p. 123-3146.

Nagy, D., 1966, The gravitational attraction of a right rectangular prism: Geophysics, v. 31, no. 2, p. 362-371.

Oppenheimer, J.M., and Sumner, J.S., 1980, Depth-to-bedrock map, Basin and Range province, Arizona: University of Arizona, Department of Geosciences, Laboratory of Geophysics, scale 1:1,000,000.

PACES, 2008, Gravity and magnetic dataset repository: PanAmerican Center for Earth and Environmental Studies (PACES), http://irpsrvgis00.utep.edu/repositorywebsite/.

Parker, J.T.C., Steinkampf, W.C., and Flynn, M.E., 2005, Hydrogeology of the Mogollon highlands, central Arizona: U.S. Geological Survey Scientific Investigations Report 2004-5294, 87 p.

Parker, R.L., 1972, The rapid calculation of potential anomalies: Geophysical Journal of the Royal Astronomical Society, v. 31, no. 4, p. 447-455. 
Pool, D.R., and Coes, A.L., 1999, Hydrogeologic investigations of the Sierra Vista subwatershed of the upper San Pedro Basin, Cochise County, southeast Arizona: U.S. Geological Survey Water-Resources Investigations Report 99-4197, 41 p.

Pool, D.R., and Dickinson, J.E., 2007, Ground-water flow model of the Sierra Vista subwatershed and Sonoran portions of the upper San Pedro basin, southeastern Arizona, United States, and northern Sonora, Mexico: U.S. Geological Survey Scientific Investigations Report 2006-5228, 48 p.

Roeske, R.H., and Werrell, W.L., 1973, Hydrologic conditions in the San Pedro River valley, Arizona, 1971: Arizona Water Commission Bulletin 4, 76 p.

Saltus, R.W., and Jachens, R.C., 1995, Gravity and basindepth maps of the Basin and Range Province, western United States: U.S. Geological Survey Geophysical Investigations GP-1012, scale 1:2,500,000.

Scarborough, R.B., 1989, Cenozoic erosion and sedimentation in Arizona, in Jenny, J.P., and Reynolds, S.J., eds., Geologic evolution of Arizona: Arizona Geological Society Digest 17, p. 515-538.

Scarborough, R.B., and Peirce, H.W., 1978, Late Cenozoic basins of Arizona, in Callender, J.F., Wilt, J.C., and Clemons, R.E., eds., Land of Cochise, Southeastern Arizona: New Mexico Geological Society Guidebook, 29th field conference, p. 253-259.

Schwartz, K.L., 1990, A geohydrological investigation of volcanic rocks using the gravity method; Galiuro mountains, Graham, Pinal, and Cochise Counties, Arizona: Tucson, Arizona, The University of Arizona, M.S. thesis, 138 p.
Shafiqullah, M., Damon, P.E., Lynch, D.J., Reynolds, S.J., Rehrig, W.A., and Raymond, R.H., 1980, K-Ar geochronology and geologic history of southwestern Arizona and adjacent areas, in Jenny, J.P., and Stone, C., eds., Studies in western Arizona: Tucson, Arizona, Arizona Geological Society Digest 12, p. 201-260.

Shipman, T.C., and Ferguson, C.A., 2006, Geologic map of the Land 7.5' Quadrangle, Cochise County, Arizona: Arizona Geological Survey Digital Geologic Map 49, scale $1: 24,000$.

Simpson, R.W., Jachens, R.C., and Blakely, R.J., 1983, AIRYROOT; a FORTRAN program for calculating the gravitational attraction of an airy isostatic root out to $166.7 \mathrm{~km}$ : U.S. Geological Survey Open-File Report 83-883, 66 p.

Smith, G.A., 1994, Climatic influences on continental deposition during late-stage filling of an extensional basin, southeastern Arizona: Geological Society of America Bulletin, v. 106, no. 9, p. 1212-1228.

Spangler, D.P., 1968, Application of the gravity survey method to watershed hydrology: Ground Water, v. 6, no. 6, p. 21-26.

U.S. Census Bureau, 2006, Annual estimates of the population for incorporated places in Arizona: U.S. Census Bureau, accessed January 6th, at http://www.census.gov/prod/ www/abs/decennial/index.htm.

Wynn, J., 2006, Mapping ground water in three dimensionsan analysis of airborne geophysical surveys of the Upper San Pedro River Basin, Cochise County, Southeastern Arizona: U.S. Geological Survey Professional Paper 1674, 33 p. 
Produced in the Western Region, Menlo Park, California Manuscript approved for publication May 21, 2010 Text edited by Peter H. Stauffer Layout and design by Judy Weathers 
